\title{
Fathers' Childcare: the Difference between Participation and Amount of Time
}

\author{
Nora Reich
}

\section{HWWI Research}

Paper 116 
Nora Reich

Hamburg Institute of International Economics (HWWI)

Heimhuder Str. 71 | 20148 Hamburg | Germany

Phone: +49 (0)40 340576 - 672 | Fax: +49 (0)40 340576 - 776

reich@hwwi.org

HWWI Research Paper

Hamburg Institute of International Economics (HWWI)

Heimhuder Str. 71 | 20148 Hamburg | Germany

Phone: +49 (0)40 340576 - 0 | Fax: +49 (0)40 340576 - 776

info@hwwi.org |www.hwwi.org

ISSN 1861-504X

Editorial Board:

Thomas Straubhaar (Chair)

Michael Bräuninger

Silvia Stiller

() Hamburg Institute of International Economics (HWWI)

February 2012

All rights reserved. No part of this publication may be reproduced, stored in a retrieval system, or transmitted in any form or by any means (electronic, mechanical, photocopying, recording or otherwise) without the prior written permission of the publisher. 


\title{
Fathers' Childcare: the Difference between Participation and Amount of Time
}

\author{
Nora Reich*
}

February 2012

\begin{abstract}
The main research question of this article is whether and how predictors of fathers' participation in childcare, defined as zero versus more than zero minutes of childcare, differ from predictors of participating fathers' amount of time on childcare, measured as minutes on the survey day. The sample is drawn from the Multinational Time Use Study (MTUS) and covers surveys from ten industrialised countries from 1987 to 2005. Results show that there are remarkable differences between factors influencing participation in childcare and factors associated with participating fathers' time spent with children. For example, the educational level has a strong impact on fathers' participation, but not on the amount of time spent on childcare. In contrast, work hours and whether data refer to a weekday or a weekend day hardly affect participation, but strongly affect fathers' time for childcare. There are also noticeable differences between the countries and between different points in time regarding factors influencing childcare participation and time. Results call for caution regarding findings from existing studies not distinguishing participation from participating fathers' childcare minutes.
\end{abstract}

JEL Classification: D13, J13,

Keywords: childcare, fatherhood, time use, selection

\section{Introduction}

Fathers' involvement in childcare has increasingly attracted attention from researchers in various fields of the social sciences. Firstly, as mothers' labour market participation has risen in most industrialised countries over the course of the last few decades, the question arises whether and how this has an effect on fathers' childcare. Secondly, numerous studies agree that fathers' engagement with their children has positive effects on children's well-being and cognitive development (Carlson and McLanahan 2004; Palkovitz 2002).

When fathers' childcare time is analysed using minutes of childcare on the survey day, this variable typically takes positive integer values, is right-skewed and shows a significant number of zeros. Zeros arise when fathers report not having spent any time on childcare during the period surveyed. In the majority of previous studies, Tobit models for censored data are applied to explain fathers' childcare

*Hamburg Institute of International Economics (HWWI) and University of Hamburg; reich@hwwi.org. 
time, as this specification assumes that the dependent variable is not observed over its full range (e.g., Sayer, Bianchi and Robinson 2004; Kalenkoski and Foster 2008; Romano and Bruzzese 2007; Wang and Bianchi 2009). But, firstly, Tobit models imply that the "non-participants", i.e. fathers reporting zero minutes of childcare, usually spend some time on childcare, but did not do so coincidentally during the survey period. Non-participants are therefore ignored or treated as an artifact of the data (Pacholok and Gauthier 2010). Pacholok and Gauthier (2010) took a closer look at fathers' participation in childcare and discovered that non-participants differ substantially from participants in terms of their social, economic, and demographic characteristics. Secondly, a recent article shows that even if the fraction of zero-value observations is large on the diary day, ordinary least square (OLS) models should be prefered to Tobit models, as, according to simulations, only OLS generates unbiased estimates (Stewart 2009). This is due to the mismatch between the short survey period of the data (the diary day) and the reference period, e.g. the whole childhood period of the child.

Hook (2010) uses Poisson regression models for count data. She argues that they - in contrast to Tobit models - do not produce negative predicted values (which would not fit to time use data) and account for the skewness of the data. However, she also treats fathers with zero childcare minutes as data artifact. In addition, Poisson models are designed for dependent variables (count data) with few values, but the number of minutes on a diary day can reach values of up to 1440 .

I employ a Probit model for participation in childcare and an OLS model for participating fathers' minutes of childcare for investigating the differences between fathers' participation in and amount of time spent on childcare. The main research question is whether and how predictors of fathers' participation in childcare, defined as zero versus more than zero minutes of childcare, differ from predictors of participating fathers' amount of time on childcare, measured as minutes on the survey day. I look at ten industrialised countries, so that cross-country differences in fathers' participation

and amount of time can be assessed. Furthermore, for some countries, two surveys are available from the last 25 years, so that changes over time from the same country are revealed. The sample is drawn from the Multinational Time Use Study (MTUS). The selected countries are Canada, Finland, France, Germany, Italy, the Netherlands, Norway, Sweden, the United Kingdom, and the United States.

The article is structured as follows. In section 2, economic and sociological theories on fathers' childcare time and their application in empirical time-use studies are discussed. Section 3 presents literature on the predictors of fathers' childcare participation and time. Then, the data, sample, model and variables are described in sections 4 and 5 . After that, descriptive results and the results of the selection model for childcare are discussed in sections 6 and 7. Finally, section 8 concludes.

\section{Fathers' childcare participation and amount of time: theo- retical background and application with time-use data}

Economic and sociological theories provide different frameworks for the explanation on the time allocation of family members. In this section, they are discussed within the context of participation and amount of time spent on childcare.

One of the most prominent economic theories on parents' allocation of time is Becker's New Home Economics (Becker 1965, 1985). According to this theory, spouses maximise a joint utility function. Utility is maximised if one spouse completely specialises in paid labour, whereas the other spouse 
specialises in household tasks, including childcare. In other words, one spouse would be a "childcare participant" while the other one - who works in the market - would be a "non-participant". Specialisation - and hence participation - is basically determined by education and experience: The spouse with the higher educational level and more work experience, i.e. the higher marketable human capital, can achieve a higher income in the market (potential wage) and thus devotes his/her time to market work. Besides human capital, a spouse's sex does play a role in Becker's model, since he assumes that women have a "biological advantage" (Becker 1981:21) for raising children. To sum up, this approach is useful for predicting participation and non-participation depending on relative human capital parameters (educational level, work experience, potential wage), and the spouse's sex.

Other theoretical approaches are less extreme than Becker's theory, as complete specialisation is viewed as only one possibility of maximised utility of the spouses. In these models, specialisation is not ruled out, but the focus is on explaining which parent does more and which one does less unpaid work.

According to the Bargaining theory (e.g. Ott 1992), spouses bargain over time allocation regrarding paid and unpaid work (including childcare). The spouse endowed with higher human capital does more market work and less unpaid work, while the other one focuses on unpaid work and works less in the market. Again, relative human capital would be the main predictor of each spouse's allocation of time.

A third economic model, developed by Akerlof and Kranton (2000), incorporates the sociological view that individuals' time use is influenced by social norms into a formal framework. According to this theory, time allocation depends on "identity". Acting out of line with prevailing norms and views in society implicates a loss of identity. Therefore, men aim at displaying masculine behaviour, while women aim at living up to the ideals of what is seen to make them "good women". Being endowed with the lower human capital and thus the lower (potential) wage than his female partner would harm a man's identity. As a consequence, and contrary to the results of the two theories presented above, he would avoid doing "women's" work, like childcare and housework, in order to compensate for his loss of identity. The equivalent sociological approach is referred to as "Doing gender" theory (West and Zimmermann 1987). A given spouse's relative human capital would have the opposite effect on childcare time compared to the Bargaining and the New Home Economics approaches.

Sociologists also provide a framework explaining differences in time use between men (instead of between spouses). It is argued that egalitarian views are more prevalent among highly educated men than among their less-educated counterparts (Blossfeld and Drobnič 2001). Thus participation would be determined a-priori, with highly educated fathers being more inclined to participate in childcare due to their egalitarian values.

In short, economists and sociologists provide a variety of theoretical approaches for fathers' childcare participation and fathers' time for childcare. However, apart from Becker's model, which clearly talks about participation versus non-participation, most theories treat childcare time as a continuous variable, referring to less and more childcare. In line with these approaches, existing empirical studies have ignored fathers' non-participation in childcare and treated it as an artifact, arguing that they constitute very few cases or that these "non-participants" are similar to participants (Pacholok and Gauthier 2010). Indeed, there are several reasons why fathers who did not participate in childcare during the survey period are not "real" non-participants. Parents are much more a selected group today than they used to be a few decades ago. The spread and increasing reliability of contraceptive 
devices have made parenting more voluntary, and the lower number of children per family could make each child more precious in the eyes of the parents (Sayer, Bianchi and Robinson 2004). In addition, changes in leisure activities over time and increased concerns about children's safety could result in parents spending more time accompanying their children today than in earlier times. Moreover, the father's role is changing in many societies, increasing the pressure on fathers to be a "good parent", i.e. to practise active fathering (Romano and Bruzzese 2007). All of these developments lead to the assumption that all fathers normally spend at least a few minutes per day with their children. Zero minutes of childcare could only occur if fathers face severe time constraints or if the child is not available (due to school or other activities) when the father is at home. In other words, relatively few fathers would report having spent zero minutes of childcare on the diary day(s), and fathers' employment and whether the data refer to a weekday or a weekend day would be the sole predictors of fathers' childcare participation.

Existing studies do not support the assumption that all fathers are usually participants. Firstly, not only a few fathers but a considerable number of them report zero minutes of childcare on the diary day in numerous industrialised countries. The share of non-participants lies between $32 \%$ in Sweden and $76 \%$ in Latvia according to MTUS data for 16 countries around the year 2000. The same study showed for Canadian fathers that some of them can legitimately be labelled as "nonparticipants". In this case, not time constraints (e.g. weekend versus weekday, work hours) but demographic and socio-economic factors are the main predictors of a father's participation in childcare (Pacholok and Gauthier 2010). In line with this result, I hypothesise that in the countries analysed in this study, fathers participating in childcare are distinct from those not participating, so that, indeed, demographic and socio-economic differences can explain childcare participation, while childcare time should be dependent on time availability, i.e. mainly determined by the day of the week and work status.

Regarding the data at hand, for some countries surveys are available at two different points in time, i.e. around 1990 and around 2000, for several countries. What reasons could there be for differences between these points in time with respect to fathers' childcare participation and time? Firstly, women's labour market participation has risen in many countries over the course of this decade (Eurostat 2012). Secondly, many countries have changed family policy legislation during the 1990s (e.g., Reich et al. 2012; Moss and Wall 2007). Thirdly, as explained above, having children is more voluntary today than it used to be, and fathers' role in society is changing. I expect that participation in childcare has risen over time. I also hypothesise that fathers' amount of childcare minutes has risen, although the expansion of public day-care facilities and the trend towards all-day schools in some countries could have shifted some childcare responsibilities from the family (both parents) to public institutions.

\section{Predictors of fathers' childcare participation and time}

Most studies on fathers' involvement with their children focus on the amount of time spent, not on fathers' participation in childcare. A noticeable exception is the recent article by Pacholok and Gauthier (2010), who applied a multinomial logit model to compare non-participants with fathers reporting low, medium and high amounts of childcare time. They find a positive effect for education for all categories of the dependent variable of childcare participation (low, medium, high versus no 
participation), a positive effect for the number of children for medium and high participation versus no participation, and a positive effect for the weekend, low amount of work hours and the female partner's employment for high versus no participation. A negative impact for at least two categories of childcare participation was found for step-parent families and long work hours. Unfortunately their analysis is limited to Canadian data and for one point in time.

As to predictors of fathers' childcare time, a clear positive impact is seen from the fathers' time for housework, his female partners' time for childcare as well as being married instead of cohabiting and being employed in the public sector (Aldous et al. 1998; Gottmann 1994; Hook 2006; Stancanelli 2003; Sullivan et al. 2009; Volling and Belsky 1991). Numerous studies also agree that the educational level has a positive effect in many countries (e.g., Cooksey and Fondell 1996; Marsiglio 1991; Sayer, Bianchi and Robinson 2004; Sayer, Gauthier and Furstenberg 2004). Only in Norway does the educational level not have an effect on fathers' childcare time (Haas and Hwang 2008; Sayer, Gauthier and Furstenberg 2004).

A negative effect on fathers' time for childcare was found for their level of involvement in market work, measured as the number of work hours or the employment status (full-time, part-time, no employment) (Aldous et al. 1998; Ishii-Kuntz and Coltrane 1992; Pleck 2007; Yeung et al. 2001; Stancanelli 2003; Sayer, Bianchi and Robinson 2004; Sayer, Gauthier and Furstenberg 2004). Furthermore, the age of the youngest child, high costs and low availability of non-parental care and the presence of other adults in the household have a negative impact (Averett et al. 2000; Cooksey and Fondell 1996; Sayer, Bianchi and Robinson 2004; Sayer, Gauthier and Furstenberg 2004).

Mixed results are found for the father's age, the number of children, and the child's sex (Cooksey and Fondell 1996; Ishii-Kuntz and Coltrane 1992; Snarey 1993; Stancanelli 2003, Sayer et al. 2004, Ishii-Kuntz and Coltrane 1992). ${ }^{1}$

To sum up, the existing empirical literature gives insights into predictors of fathers' childcare involvement. Nonetheless, several questions remain unanswered. Firstly, most studies focus on the predictors of participating fathers' time for childcare. Yet, as argued in the previous section, predictors for participation in childcare can be very different from predictors for the amount of time. Secondly, fathers' participation and participating fathers' amount of time for childcare have not been analysed in detail across different countries. Thirdly, changes over time in fathers' childcare participation in a particular country have not been assessed in detail so far.

\section{Data and sample}

This study is based on data from the Multinational Time Use Study (MTUS, 2010), versions 5.52, 5.53 and 5.80. The MTUS provides representative samples of individual data with diary records from 20 countries from the 1960s until the 2000s. The analysis is restricted to countries which feature the main variables that affect fathers' involvement in childcare according to related empirical literature. In particular, the variable "partner's employment status" considerably reduces the number of surveys available for analysing the research question. The following surveys are included: Canada (1992,

\footnotetext{
${ }^{1}$ Recently, some researchers have pooled data from several countries to investigate the impact of macro-level factors on fathers' participation in domestic work. But as this paper focuses on individual-level data, I refrain from reviewing literature on macro-level predictors in this article. For an overview of these factors for fathers' childcare see Reich et al. 2012.
} 
1998), Finland (1987, 1999), France (1998), Italy (1989, 2001), Germany (1991, 2001), Netherlands (2000, 2005), Norway (1990, 2005), Sweden (1991, 2001), United Kingdom (2000) and United States (2003). In most countries, only one day has been surveyed, hence one 24-hour diary is available. For five countries, more than one diary day was recorded. Since this article focuses on cross-country differences, one diary day per person has been randomly selected for all countries, in order to make the results comparable. The mode of data collection and the time intervals vary slightly between countries and surveys. Diaries are filled out during the day as activities take place, at the end of the day, or on the next day. For matters of simplifications, the terms "diary day" and "survey day" are used interchangeably for the day to which the diary refers. Required time intervals range from free intervals, i.e., at least one minute, to 15-minute-intervals. Biases arising from these differences are assumed to be rather small, as cross-country differences have been successfully carried out before with the same data.

Sixty-nine different main activities are recorded. The main activity of interest is childcare, which includes the following activities with or for children: preparing meals, feeding, putting to bed, medical and body care, looking after the child, helping with homework, reading something to the child, playing with the child and talking to the child. Thus, all kinds of activities primarily done for or with a child are considered as childcare.

The sample consists of fathers who are married or cohabiting and are between 20 and 55 years old and have at least one child below the age of 18 in the household.

\section{Models and variables}

The two dependent variables of interest are participation in childcare, defined as zero versus more than zero minutes of childcare on the survey day, and minutes of childcare on the survey day. For participation, I apply a probit model as empirical strategy (see, e.g. Jones 2009). Participation in childcare is a binary variable, denoted as $Y$, and assumed to depend on $k$ observable variables $X_{1}, \ldots, X_{k}$ and on an error term $u$ :

$$
Y=\sum \beta_{k} X_{k}+u
$$

The $\beta_{k}$-coefficients represent the effects of the variables $X_{1}, \ldots, X_{k}$. The question of interest is the probability of participation in childcare, i.e., that $Y$ equals 1 :

$$
\begin{gathered}
P(Y=1)=P\left(Y=1 \mid X_{1}, \ldots, X_{k}\right) \\
P(Y=1 \mid X)
\end{gathered}
$$

Assuming that the error term is normally distributed $(u \sim N(0,1))$, the standard Probit model is given by

$$
P\left(Y=1 \mid X=\Phi\left(\sum \beta_{k} X_{k}\right)=\int_{-\infty}^{x} \frac{1}{\sqrt{2 \pi}} \exp \left(\frac{-x^{2}}{2}\right) d x\right.
$$


For minutes of childcare, as stated above, many existing studies are based on Tobit models, as fathers with more than zero minutes of childcare time should be representative of the population of all fathers. In contrast, in my analysis, the sample of participating fathers should be representative for the population of participating fathers only. Therefore, I apply ordinary least square (OLS) models for analysing father's minutes of childcare. ${ }^{2}$ This is the OLS equation:

$$
Y=\beta_{0}+\beta_{1} X_{1}+\ldots+\beta_{k} X_{k}+u
$$

The dependent variable $Y$ is the number of childcare minutes of participating fathers. $\beta_{0}, \ldots, \beta_{k}$ are the parameters that are estimated, $X_{1}, \ldots, X_{k}$ are vectors of observable variables (i.e. independent variables), and $u$ the unobservable error term. The choice of independent variables is made according to related theoretical and empirical literature on fathers' time for domestic work. The models account for the age of the youngest child in three categories (0-4 years, 5-12 years, 13-17 years), as a continuous variable is not available for all countries. The models also include the number of children, the age of the father and its square, his educational level, his employment status, his partner's employment status, weekday versus weekend day, and a dummy for the survey year if more than one survey of a certain country is considered. In addition, participation in housework, defined as zero minutes versus more than zero minutes of housework on the survey day, is included in the participation model, while the number of housework minutes is only included as an independent variable in the model for minutes of childcare.

Educational level is coded into three categories: lower than completed secondary education (not completed ISCED ${ }^{3}$ level 3), completed secondary education (ISCED level 3 or 4), and post-secondary education (ISCED level 5 or higher). As to both parents' employment status, it is distinguished between not employed, part-time employment, full-time employment and employment with unknown work hours. This last category is only included in some of the surveys, and presumably covers mostly self-employed workers whose work hours show a lot of variation. Besides unemployed fathers, the group of fathers stated as being "not employed" includes those that are not working for any other reason, e.g. students, retirees and homemakers. ${ }^{4}$ Employment status refers to the usual work arrangement, not to the number of hours on the survey day. The dummy variable "weekend" indicates whether the diary refers to a weekend day or a weekday. The estimates are carried out for each country separately, in order to catch cross-national differences. Summary statistics and a detailed definition of variables are listed in the appendix.

\footnotetext{
${ }^{2}$ Another possibility would be the application of a Heckman selection model, consisting of a Probit estimate for childcare participation, and a main equation for minutes of childcare which includes a correction factor for selection into childcare participation. However, this procedure requires that at least one explanatory variable affects childcare participation and is therefore included in the probit equation, but does not affect childcare time and is not included in the main equation for minutes of childcare. As no variable could be identified to meet these requirements in the samples of all countries analysed, the first mentioned procedure is applied. Nevertheless, the selection model is explored as part of the sensitivity analysis.

${ }^{3}$ International Standard Classification of Education.

${ }^{4}$ If students are working, they are not classified as not working, but belong to the other groups (part-time or full-time employment or employment with unknown work hours). The share of students in the category "not employed" is below $12 \%$ in all countries but Finland (23.9\%) and Norway $(21.4 \%)$.
} 


\section{Descriptive findings on fathers' childcare participation and minutes}

Great variation in fathers' childcare participation rates and minutes spent on childcare can be found between the countries analysed and between different survey years of countries for which two surveys are available. The participation rate ranges from $28.1 \%$ in Italy in 1989 to $59.7 \%$ in Sweden in 1991 (see figure 1). Sweden, Norway and the United States are the countries with the highest participation rates, while the United Kingdom, Finland, France and Italy show the lowest rates. This supports earlier results from Pacholok and Gauthier (2010), who computed raw participation rates for several industrialised countries and found high participation rates for Sweden and Norway and lower rates for the United Kingdom, Finland, Italy and Germany.

In Norway, the Netherlands, Canada, Finland and Italy, the participation rate has increased from the first survey around 1990 to the second survey around 2000. However, in Germany, less fathers participated in childcare on the survey day in 2001 than in $1991 .{ }^{5}$ In Norway and Sweden, participation rates are high in both surveys - 1990/1991 and 2000/2001 - and they differ less than one percentage point from one another.

What underlying structure can be detected, does the distribution follow common classifications of countries? Researchers have grouped countries according to welfare state regimes, in terms of their general political institutions (Esping-Andersen 1990), family policy (Gauthier and Hatzius 1997; Korpi 2000; Mischke 2011), paid and unpaid work (Gornick and Meyers 2004) as well as gender relations (Galvez-Munoz et al. 2011; Korpi 2000). Generally, the Scandinavian countries as well as the Netherlands ${ }^{6}$ are classified as social democratic welfare states, Germany, Italy and France (and other continental European countries) are referred to as conservative welfare states, and the United Kingdom, the United States and Canada belong to the liberal welfare states. In terms of these categories, no clear pattern can be derived from the raw results for fathers' participation in childcare. For example, with regard to the Scandinavian countries and the Netherlands, i.e. social democratic welfare states, Sweden and Norway show high participation rates, but the Netherlands and Finland medium and low rates, respectively. Accordingly, the liberal welfare states United States, the United Kingdom and Canada, exhibit very different participation rates. France, Germany and Italy, conservative welfare states, exhibit medium and low participation rates.

Looking at the average number of minutes of participating fathers on the survey day, the order of countries turns out to be very different from the order of participation rates (see figure 2). The number of childcare minutes ranges from 38 minutes in the United Kingdom in 2000 to over 102 minutes in Canada in 1998. A low amount of childcare time for British fathers has been found in other studies as well. Sullivan et al. (2009) compare fathers with children below the age of five in the United Kingdom, Norway and Sweden. They find that British fathers' childcare time is much lower than that of their Scandinavian counterparts, and point to the fact that work hours for men in the United Kingdom are among the longest of the European Union member states.

Canadian fathers in 1992 show the second highest number of minutes, followed by Norway in 1990

\footnotetext{
${ }^{5}$ One reason for the decrease in fathers' childcare participation might be the expansion of the duration of parental leave during the 1980s and 1990s. As a result, mothers markedly reduced their hours of market work (Merz 2004), which could have had an impact on the gendered specialisation in unpaid labour at home.

${ }^{6}$ Several authors assign the Netherlands to the conservative group instead of the social-democratic group, see discussion in Mischke (2011).
} 
Figure 1:

Fathers' participation in childcare on the diary day in ten industrialised countries, 1987-2005

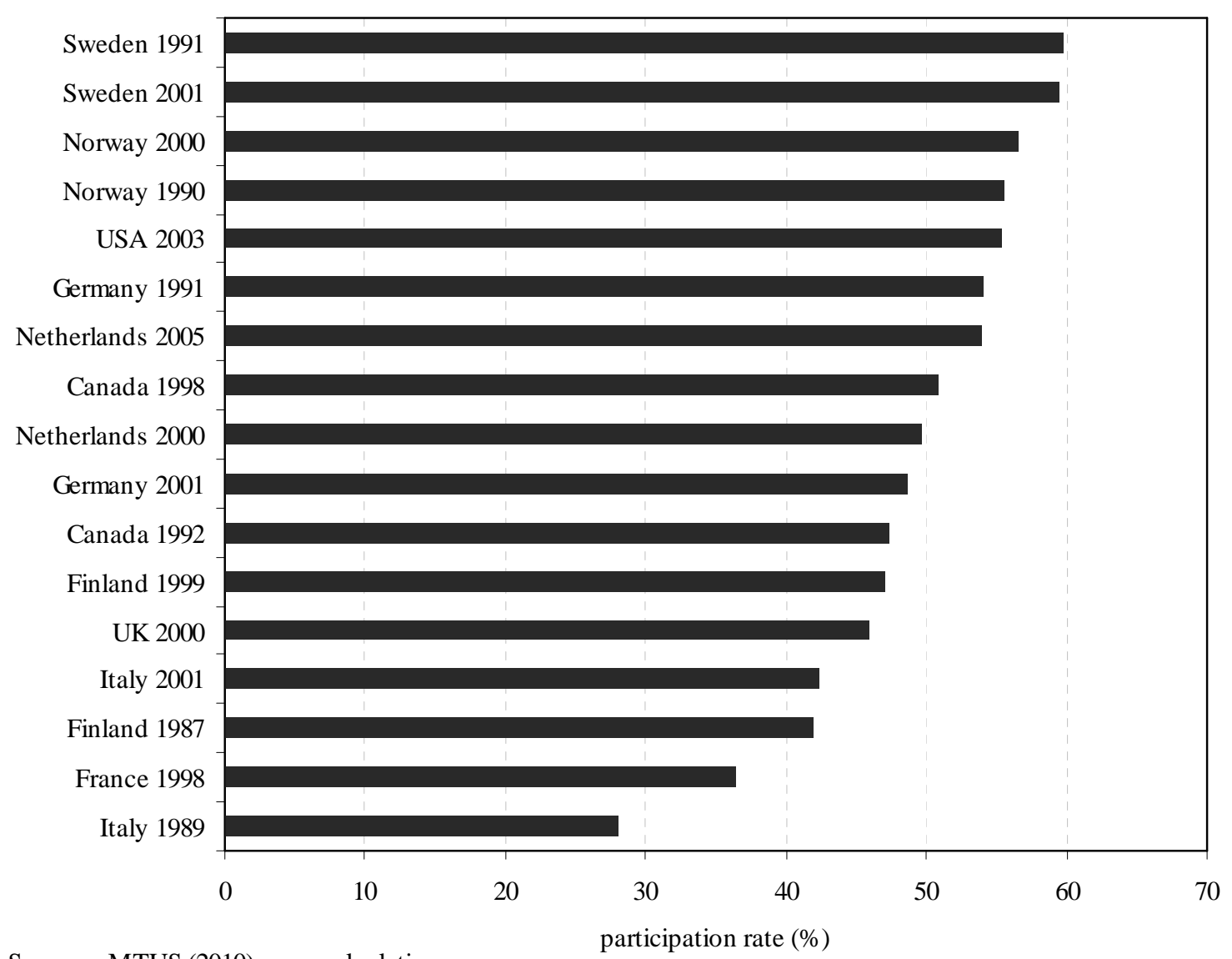

Sources: MTUS (2010); own calculations.

and Finland in 1999. Besides the United Kingdom, the United States in 2003 and Sweden in 2001 show a rather low number of minutes at less than 60. In Canada, Finland, Italy and Germany, the number of minutes is higher in the latest survey than in the earlier survey. This is consistent with the results of existing studies that find an increase in the amount of time fathers spend with their children over time (Gershuny and Sullivan 2003; Sayer, Bianchi and Robinson 2004; Gauthier et al. 2004; Bianchi 2000). In contrast, in Norway, the Netherlands, and Sweden, it is lower around the year 2000 than around 1990. The finding for Norway and Sweden contradicts the results of Gauthier et al. (2004). One reason for the decrease in the amount of time Norwegian fathers spend with their children may be the extension of public childcare facilities, as Kitterod and Pettersen (2006) suggest for their country; and the situation might be similar in Sweden. Similar to the participation rates, countries belonging to the liberal and social-democratic welfare states show very distinct patterns for fathers' childcare time. In conservative welfare states, fathers' average daily minutes of childcare are medium to low.

Comparing fathers' average participation and minutes across countries, one cannot conclude that high participation by fathers in childcare results in a larger amount of time spent on childcare by 
Figure 2:

Average number of childcare minutes on the diary day of participating fathers in ten indus trialis ed countries 1987-2005

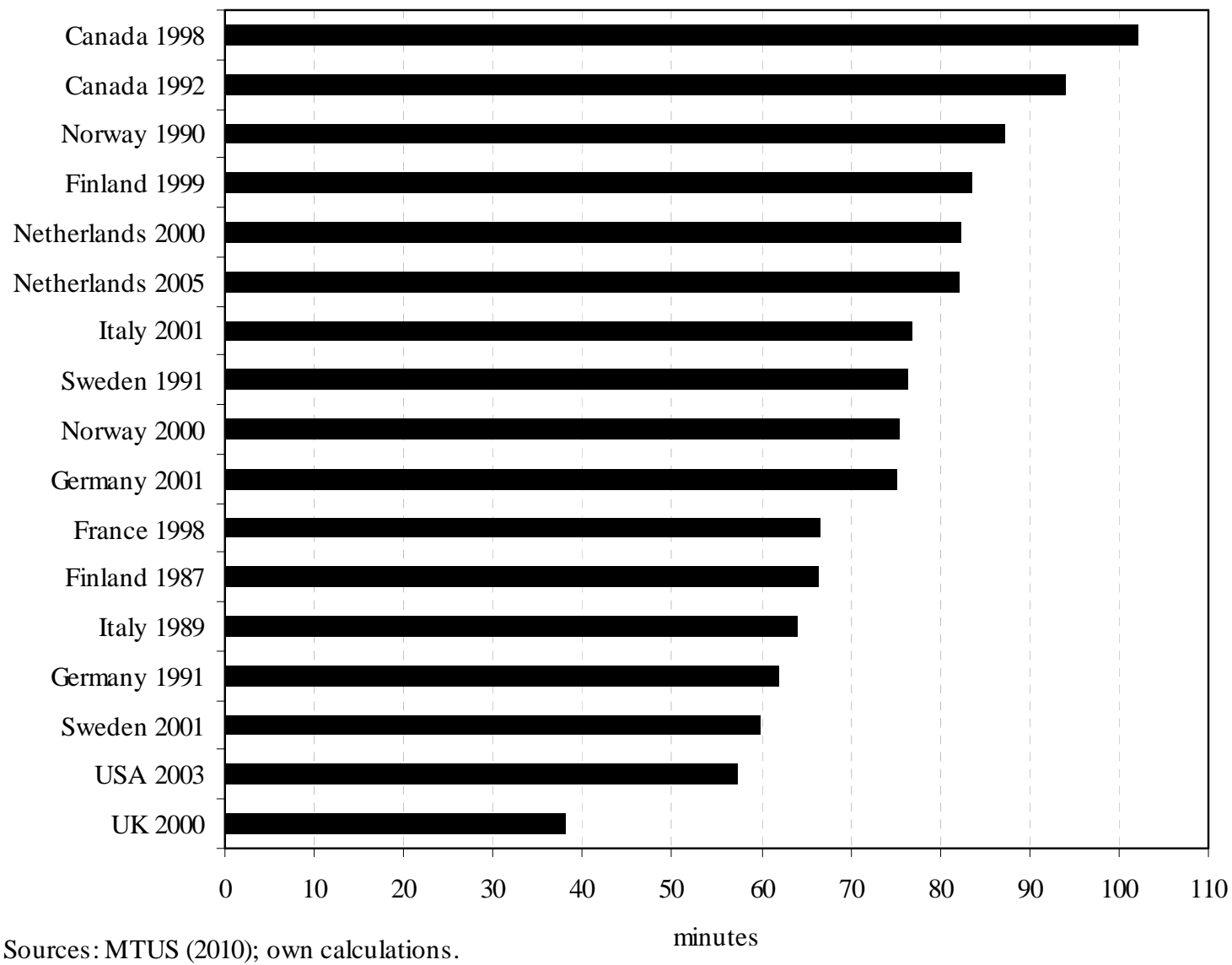

participating fathers. For example, the Swedish survey from 2001 shows the second-highest participation rate, but the third-lowest number of minutes. Likewise, participation is quite high in the United States, but the amount of time is the second lowest. On the contrary, participation rates are among the lowest for Finland in 1999, but Finnish fathers participating in childcare do so for more than 83 minutes on average on the survey day. These contrasts between participation and amount of time within one country lead to the question whether predictors for these different measures of childcare are distinct as well.

\section{Fathers and childcare: participation and time}

\subsection{Participation in childcare}

Table 1 displays the marginal effects for the Probit equation for fathers' participation in childcare in the countries analysed in this study. According to these results, the age of the youngest child is the 
only variable with a consistent negative effect across all countries. If the youngest child is between 5 and 12 years old instead of younger than 5 years, the likelihood of fathers participating in childcare is significantly reduced by between $15 \%$ (Italy) and 36\% (Sweden). If the child is between 13 and 17 years old, the likelihood of participation is reduced by between 33\% (Italy) and 58\% (Netherlands, Norway).

Negative effects also arise from the fathers' employment, but only in five of the ten countries analysed. In Italy and the United States, participation is significantly reduced through part-time work compared to no employment by about $10 \%$. Full-time employment reduces participation in Canada, France, Italy, Norway and the United States; the effect ranges from $6 \%$ in Italy to $17 \%$ in Canada. An employment in the category "unknown work hours" reduces the likelihood of fathers' participating in childcare by about $10 \%$ in Italy and France. Fathers' childcare time is independent from the work status in Finland, Germany, the Netherlands, Sweden and the United Kingdom.

Surprisingly, fathers participate less in childcare on weekend days than on weekdays in Canada, Sweden and the United States. For countries with two surveys, the likelihood of fathers' childcare participation is lower in the older survey in Canada, Finland and Italy, while there is no difference in Germany, Norway and Sweden.

In all countries but Norway and the United Kingdom, higher education positively affects fathers' childcare time, the impact ranging from almost $5 \%$ in Germany to $28 \%$ in the United States. Even fathers with a medium educational level have a higher likelihood to participate in childcare than their lesser-educated counterparts in five of the ten countries analysed (Canada, Finland, Italy, Sweden, United States).

Contrary to expectations, the employment status of the female partner affects fathers' childcare participation in three countries only. In Italy, Sweden and the United States, the likelihood of participation is significantly increased if the partner is working part-time or full-time instead of not working. In these countries as well as in France and the Netherlands, the partner's full-time employment has a positive effect, ranging from $2 \%$ in the United States to $17 \%$ in the Netherlands. The number of children increases the likelihood of fathers participating in childcare by about $3 \%$ in the United States.

A consistent positive correlation can be found for fathers' participation in housework. Participation in housework increases the likelihood of childcare participation by about $18 \%$ in France, by almost $30 \%$ in the Netherlands. But contrary to the interpretation of the other variables, this finding might not reflect a causal relationship, i.e. that housework participation affects childcare participation. Firstly, it is likely that housework can be a result of childcare, as, for example, rooms in which children have played need to be tidied up. Secondly, the relationship can be spurious, if another factor (e.g., family-orientation) affects participation in both types of unpaid work positively. ${ }^{7}$

\footnotetext{
${ }^{7}$ Sensitivity analyses have shown that the exclusion of this variable does not change the qualitative effect of the other covariates.
} 
Table 1 (part I): Fathers' participation in childcare

Probit model, participation equation, marginal effects, standard errors in parenthesis dependent variable: childcare participation

$\begin{array}{ccccc}\mathrm{CA} & \mathrm{FI} & \mathrm{FR} & \mathrm{GE} & \mathrm{IT} \\ (\mathrm{N}=2241) & (\mathrm{N}=1344) & (\mathrm{N}=2169) & (\mathrm{N}=3915) & (\mathrm{N}=9173) \\ (1992, & (1987, & (1998) & (1991, & (1989 \\ 1998) & 1999) & & 2001) & 2001)\end{array}$

\begin{tabular}{|c|c|c|c|c|c|c|}
\hline \multirow{3}{*}{$\begin{array}{l}\text { age of the youngest } \\
\text { child }\end{array}$} & $0-4$ & ref. & ref. & ref. & ref. & ref. \\
\hline & $5-12$ & $\begin{array}{c}-0.269^{* * *} \\
(0.026)\end{array}$ & $\begin{array}{c}-0.320^{* * *} \\
(0.032)\end{array}$ & $\begin{array}{c}-0.235^{* * *} \\
(0.025)\end{array}$ & $\begin{array}{c}-0.271^{* * *} \\
(0.021)\end{array}$ & $\begin{array}{c}-0.154^{* * *} \\
(0.014)\end{array}$ \\
\hline & $13-17$ & $\begin{array}{c}-0.551^{* * *} \\
(0.018)\end{array}$ & $\begin{array}{c}-0.500^{* * *} \\
(0.025)\end{array}$ & $\begin{array}{c}-0.371^{* * *} \\
(0.022)\end{array}$ & $\begin{array}{c}-0.541^{* * *} \\
(0.019)\end{array}$ & $\begin{array}{c}-0.327^{* * *} \\
(0.013)\end{array}$ \\
\hline \multicolumn{2}{|l|}{ no. of children } & $\begin{array}{c}0.019 \\
(0.015)\end{array}$ & $\begin{array}{c}0.007 \\
(0.020)\end{array}$ & $\begin{array}{c}0.001 \\
(0.013)\end{array}$ & $\begin{array}{l}-0.011 \\
(0.012)\end{array}$ & $\begin{array}{c}0.004 \\
(0.008)\end{array}$ \\
\hline \multicolumn{2}{|l|}{ father's age } & $\begin{array}{c}0.021 \\
(0.017)\end{array}$ & $\begin{array}{l}-0.017 \\
(0.022)\end{array}$ & $\begin{array}{c}0.016 \\
(0.016)\end{array}$ & $\begin{array}{c}0.009 \\
(0.014)\end{array}$ & $\begin{array}{c}0.008 \\
(0.009)\end{array}$ \\
\hline \multicolumn{2}{|l|}{ father's age squared } & $\begin{array}{l}-0.000 \\
(0.000)\end{array}$ & $\begin{array}{c}0.000 \\
(0.000)\end{array}$ & $\begin{array}{l}-0.000 \\
(0.000)\end{array}$ & $\begin{array}{l}-0.000 \\
(0.000)\end{array}$ & $\begin{array}{c}-0.000^{* *} \\
(0.000)\end{array}$ \\
\hline \multirow[t]{2}{*}{ educational level } & $\begin{array}{l}\text { low } \\
\text { medium }\end{array}$ & $\begin{array}{c}\text { ref. } \\
0.139^{* * *} \\
(0.037)\end{array}$ & $\begin{array}{c}\text { ref. } \\
0.121^{* * *} \\
(0.038)\end{array}$ & $\begin{array}{c}\text { ref. } \\
0.037 \\
(0.033)\end{array}$ & $\begin{array}{c}\text { ref. } \\
-0.045^{*} \\
(0.025)\end{array}$ & $\begin{array}{c}\text { ref. } \\
0.116^{* * *} \\
(0.015)\end{array}$ \\
\hline & high & $\begin{array}{c}0.189^{* * *} \\
(0.031)\end{array}$ & $\begin{array}{c}0.141^{* * *} \\
(0.041)\end{array}$ & $\begin{array}{c}0.141^{* * *} \\
(0.036)\end{array}$ & $\begin{array}{l}0.046^{*} \\
(0.024)\end{array}$ & $\begin{array}{c}0.238^{* * *} \\
(0.022)\end{array}$ \\
\hline \multirow[t]{3}{*}{ fathers' employment } & $\begin{array}{l}\text { not employed } \\
\text { part-time }\end{array}$ & $\begin{array}{c}\text { ref. } \\
0.224^{* *} \\
(0.087)\end{array}$ & $\begin{array}{c}\text { ref. } \\
0.038 \\
(0.141)\end{array}$ & $\begin{array}{c}\text { ref. } \\
-0.105 \\
(0.067)\end{array}$ & $\begin{array}{c}\text { ref. } \\
-0.009 \\
(0.071)\end{array}$ & $\begin{array}{c}\text { ref. } \\
-0.103^{* * *} \\
(0.033)\end{array}$ \\
\hline & full-time & $\begin{array}{l}-0.169 * \\
(0.039)\end{array}$ & $\begin{array}{l}-0.024 \\
(0.067)\end{array}$ & $\begin{array}{c}-0.098^{* *} \\
(0.043)\end{array}$ & $\begin{array}{l}-0.048 \\
(0.038)\end{array}$ & $\begin{array}{c}-0.057^{* *} \\
(0.027)\end{array}$ \\
\hline & $\begin{array}{l}\text { unknown work } \\
\text { hours }\end{array}$ & $\begin{array}{c}0.124 \\
(0.147)\end{array}$ & $\begin{array}{c}0.020 \\
(0.089)\end{array}$ & $\begin{array}{c}-0.100^{* *} \\
(0.045)\end{array}$ & $\begin{array}{c}0.118 \\
(0.011)\end{array}$ & $\begin{array}{c}-0.104^{* * *} \\
(0.025)\end{array}$ \\
\hline \multirow{4}{*}{$\begin{array}{l}\text { partner's } \\
\text { employment }\end{array}$} & not employed & ref. & ref. & ref. & ref. & ref. \\
\hline & part-time & $\begin{array}{l}-0.033 \\
(0.035)\end{array}$ & - & $\begin{array}{c}0.020 \\
(0.031)\end{array}$ & $\begin{array}{c}0.010 \\
(0.021)\end{array}$ & $\begin{array}{l}0.040^{*} \\
(0.022)\end{array}$ \\
\hline & full-time & $\begin{array}{c}0.021 \\
(0.027)\end{array}$ & - & $\begin{array}{c}0.058^{* *} \\
(0.029)\end{array}$ & $\begin{array}{c}0.011 \\
(0.025)\end{array}$ & $\begin{array}{c}0.039^{* *} \\
(0.016)\end{array}$ \\
\hline & $\begin{array}{l}\text { unknown work } \\
\text { hours }\end{array}$ & - & $\begin{array}{c}0.018 \\
(0.041)\end{array}$ & $\begin{array}{c}0.034 \\
(0.043)\end{array}$ & $\begin{array}{l}0.0435 \\
(0.035)\end{array}$ & $\begin{array}{c}0.018 \\
(0.024)\end{array}$ \\
\hline day of the week & $\begin{array}{l}\text { weekday } \\
\text { weekend }\end{array}$ & $\begin{array}{c}\text { ref. } \\
-0.044^{*} \\
(0.026)\end{array}$ & $\begin{array}{c}\text { ref. } \\
0.010 \\
(0.033)\end{array}$ & $\begin{array}{c}\text { ref. } \\
-0.011 \\
(0.024)\end{array}$ & $\begin{array}{c}\text { ref. } \\
0.004 \\
(0.020)\end{array}$ & $\begin{array}{c}\text { ref. } \\
-0.000 \\
(0.011)\end{array}$ \\
\hline \multicolumn{2}{|l|}{ housework participation } & $\begin{array}{c}0.227^{* * *} \\
(0.023)\end{array}$ & $\begin{array}{c}0.180^{* * *} \\
(0.031)\end{array}$ & $\begin{array}{c}0.193^{* * *} \\
(0.022)\end{array}$ & $\begin{array}{c}0.211^{* * *} \\
(0.019)\end{array}$ & $\begin{array}{c}0.186^{* * *} \\
(0.011)\end{array}$ \\
\hline time of survey & wave 1 & $\begin{array}{c}-0.055^{* *} \\
(0.024) \\
\text { ref. }\end{array}$ & $\begin{array}{c}-0.125^{* * *} \\
(0.042) \\
\text { ref. }\end{array}$ & - & $\begin{array}{c}0.025 \\
(0.022) \\
\text { ref. }\end{array}$ & $\begin{array}{c}-0.101^{* * *} \\
(0.017) \\
\text { ref. }\end{array}$ \\
\hline Pseudo R2 & & 0.2106 & 0.2409 & 0.1681 & 0.1927 & 0.1644 \\
\hline
\end{tabular}

Significance levels: $\mathrm{p}<0.01:^{* * *}, \mathrm{p}<0.05:^{* *}, \mathrm{p}<0.10:^{*}, \mathrm{p}<0.11:\left(^{*}\right)$

No dummy indicating survey years for the Netherlands due to the small sample size.

Sources: MTUS (2010); own calculations. 
Table 1 (continued): Fathers' participation in childcare

Probit model, participation equation, marginal effects, standard errors in parenthesis dependent variable: childcare participation

\begin{tabular}{|c|c|c|c|c|c|c|}
\hline & & $\begin{array}{l}\text { NL } \\
(\mathrm{N}=426) \\
(2000 \\
2005)\end{array}$ & $\begin{array}{c}\mathrm{NO} \\
(\mathrm{N}=930) \\
(1990 \\
2000)\end{array}$ & $\begin{array}{c}\text { SW } \\
(\mathrm{N}=1164) \\
(1991 \\
2000)\end{array}$ & $\begin{array}{c}\text { UK } \\
(\mathrm{N}=1110) \\
(2000)\end{array}$ & $\begin{array}{c}\text { USA } \\
(\mathrm{N}=10364) \\
(2003)\end{array}$ \\
\hline \multirow{3}{*}{$\begin{array}{l}\text { age of the youngest } \\
\text { child }\end{array}$} & $0-4$ & ref. & ref. & ref. & ref. & ref. \\
\hline & $5-12$ & $\begin{array}{l}-0.339 * * * \\
(0.063)\end{array}$ & $\begin{array}{c}-0.330^{* * *} \\
(0.045)\end{array}$ & $\begin{array}{c}-0.362^{* * *} \\
(0.040)\end{array}$ & $\begin{array}{c}-0.337^{* * *} \\
(0.035)\end{array}$ & $\begin{array}{c}-0.197^{* * *} \\
(0.012)\end{array}$ \\
\hline & $13-17$ & $\begin{array}{l}-0.583^{* * *} \\
(0.048)\end{array}$ & $\begin{array}{c}-0.584^{* * *} \\
(0.042)\end{array}$ & $\begin{array}{c}-0.562^{* * *} \\
(0.040)\end{array}$ & $\begin{array}{c}-0.556^{* * *} \\
(0.025)\end{array}$ & $\begin{array}{c}-0.412^{* * *} \\
(0.015)\end{array}$ \\
\hline \multicolumn{2}{|l|}{ no. of children } & $\begin{array}{l}0.059 \\
(0.037)\end{array}$ & $\begin{array}{c}0.034 \\
(0.026)\end{array}$ & $\begin{array}{c}0.023 \\
(0.021)\end{array}$ & $\begin{array}{l}-0.007 \\
(0.019)\end{array}$ & $\begin{array}{c}0.035^{* * *} \\
(0.006)\end{array}$ \\
\hline \multicolumn{2}{|l|}{ father's age } & $\begin{array}{l}-0.021 \\
(0.047)\end{array}$ & $\begin{array}{l}-0.030 \\
(0.027)\end{array}$ & $\begin{array}{c}0.002 \\
(0.023)\end{array}$ & $\begin{array}{c}0.022 \\
(0.021)\end{array}$ & $\begin{array}{c}0.032^{* * *} \\
(0.006)\end{array}$ \\
\hline \multicolumn{2}{|l|}{ father's age squared } & $\begin{array}{l}0.000 \\
(0.000)\end{array}$ & $\begin{array}{c}0.000 \\
(0.000)\end{array}$ & $\begin{array}{l}-0.000 \\
(0.000)\end{array}$ & $\begin{array}{l}-0.000 \\
(0.000)\end{array}$ & $\begin{array}{c}-0.000^{* * *} \\
(0.000)\end{array}$ \\
\hline \multirow[t]{2}{*}{ educational level } & $\begin{array}{l}\text { low } \\
\text { medium }\end{array}$ & $\begin{array}{l}\text { ref. } \\
0.051 \\
(0.082)\end{array}$ & $\begin{array}{c}\text { ref. } \\
-0.065 \\
(0.065)\end{array}$ & $\begin{array}{c}\text { ref. } \\
0.068^{*} \\
(0.040)\end{array}$ & $\begin{array}{c}\text { ref. } \\
0.013 \\
(0.040)\end{array}$ & $\begin{array}{c}\text { ref. } \\
0.135^{* * *} \\
(0.019)\end{array}$ \\
\hline & high & $\begin{array}{l}0.140^{*} \\
(0.079)\end{array}$ & $\begin{array}{c}0.035 \\
(0.068)\end{array}$ & $\begin{array}{c}0.130 * * * \\
(0.041)\end{array}$ & $\begin{array}{c}0.026 \\
(0.045)\end{array}$ & $\begin{array}{c}0.283^{* * *} \\
(0.018)\end{array}$ \\
\hline \multirow[t]{3}{*}{ fathers' employment } & $\begin{array}{l}\text { not employed } \\
\text { part-time }\end{array}$ & $\begin{array}{l}\text { ref. } \\
-0.059 \\
(0.168)\end{array}$ & $\begin{array}{c}\text { ref. } \\
-0.049 \\
(0.119)\end{array}$ & $\begin{array}{c}\text { ref. } \\
0.026 \\
(0.115)\end{array}$ & $\begin{array}{c}\text { ref. } \\
-0.015 \\
(0.116)\end{array}$ & $\begin{array}{c}\text { ref. } \\
-0.106^{* * *} \\
(0.034)\end{array}$ \\
\hline & full-time & $\begin{array}{l}-0.100 \\
(0.107)\end{array}$ & $\begin{array}{l}-0.131^{*} \\
(0.071)\end{array}$ & $\begin{array}{c}0.008 \\
(0.052)\end{array}$ & $\begin{array}{l}-0.088 \\
(0.063)\end{array}$ & $\begin{array}{c}-0.083^{* * *} \\
(0.020)\end{array}$ \\
\hline & $\begin{array}{l}\text { unknown work } \\
\text { hours }\end{array}$ & - & $\begin{array}{l}-0.073 \\
(0.119)\end{array}$ & - & - & - \\
\hline \multirow{4}{*}{$\begin{array}{l}\text { partner's } \\
\text { employment }\end{array}$} & not employed & ref. & ref. & ref. & ref. & ref. \\
\hline & part-time & $\begin{array}{l}0.038 \\
(0.061)\end{array}$ & $\begin{array}{c}0.032 \\
(0.054)\end{array}$ & $\begin{array}{l}0.106^{*} \\
(0.044)\end{array}$ & $\begin{array}{c}0.031 \\
(0.041)\end{array}$ & $\begin{array}{c}0.060 * * * \\
(0.014)\end{array}$ \\
\hline & full-time & $\begin{array}{l}0.170^{*} \\
(0.094)\end{array}$ & $\begin{array}{l}-0.045 \\
(0.055)\end{array}$ & $\begin{array}{l}0.078^{*} \\
(0.045)\end{array}$ & $\begin{array}{l}-0.069 \\
(0.045)\end{array}$ & $\begin{array}{l}0.023^{*} \\
(0.012)\end{array}$ \\
\hline & $\begin{array}{l}\text { unknown work } \\
\text { hours }\end{array}$ & - & - & - & - & - \\
\hline day of the week & $\begin{array}{l}\text { weekday } \\
\text { weekend }\end{array}$ & $\begin{array}{l}\text { ref. } \\
0.072 \\
(0.062)\end{array}$ & $\begin{array}{c}\text { ref. } \\
-0.048 \\
(0.041)\end{array}$ & $\begin{array}{c}\text { ref. } \\
-0.065^{* *} \\
(0.032)\end{array}$ & $\begin{array}{c}\text { ref. } \\
0.031 \\
(0.033)\end{array}$ & $\begin{array}{c}\text { ref. } \\
-0.111^{* * *} \\
(0.010)\end{array}$ \\
\hline \multicolumn{2}{|c|}{ housework participation } & $\begin{array}{l}0.298^{* * *} \\
(0.054)\end{array}$ & $\begin{array}{c}0.260^{* * *} \\
(0.044)\end{array}$ & $\begin{array}{c}0.253^{* * *} \\
(0.040)\end{array}$ & $\begin{array}{c}0.245^{* * *} \\
(0.035)\end{array}$ & $\begin{array}{c}0.199^{* * *} \\
(0.010)\end{array}$ \\
\hline \multirow[t]{2}{*}{ time of survey } & wave 1 & - & $\begin{array}{c}0.001 \\
(0.040)\end{array}$ & $\begin{array}{l}-0.001 \\
(0.034)\end{array}$ & - & - \\
\hline & wave 2 & - & ref. & ref. & - & - \\
\hline Pseudo R2 & & 0.2578 & 0.2756 & 0.2284 & 0.2328 & 0.1366 \\
\hline
\end{tabular}

Significance levels: $\mathrm{p}<0.01:^{* * *}, \mathrm{p}<0.05$ :** $^{*} \mathrm{p}<0.10$ : $^{*}, \mathrm{p}<0.11$ : $\left.^{*}\right)$

Sources: MTUS (2010); own calculations. 
If childcare participation were only an artifact, and non-participants did not differ in terms of socioeconomic characteristics, time availability - best captured by the dummy "weekend" - would be the sole predictor of fathers' participation. However, results from these estimates show that whether the survey day is a weekday or weekend has no influence on fathers' participation in childcare in seven of the ten countries, and influences it negatively in three of them. Even fathers' work status, which could also be interpreted as a time-availability indicator, has rather limited effects. Instead, firstly, the age of the youngest child is a strong predictor, indicating that fathers' participation depends on the overall amount of childcare a child needs, as this declines with increasing age. Secondly, the educational level has a strong effect in most countries, supporting the assumption that highly educated fathers are the forerunners of modern gender roles.

In the models presented above, all variables refer to differences between fathers. However, economic theory predicts that parents' allocation of time depends on resources relative to their partner's. Therefore, estimates have been carried out replacing father's work status and partner's work status by father's work status in relation to his partner's. ${ }^{8}$ The following four categories are accounted for:

1. both not employed or part-time employment (reference)

2. father full-time or unknown work hours, partner not

3. partner full-time or unknown work hours, father not

4. both full-time or unknown work hours

The results are presented in table 2. In Canada, France and the United Kingdom, the likelihood of fathers' childcare participation is smaller if only the father works full-time or has unknown work hours, but the partner not (i.e. she is part-time employed or not employed), compared to the reference category. Italian fathers are more inclined to participate in childcare if only the mother works full-time or has unknown work hours, but British fathers participate less in the same circumstances. If both work full-time or unknown work hours, the likelihood of fathers participating in childcare is significantly lower in Norway and the United Kingdom. Hence fathers' childcare participation is independent from their work status in relation to their spouse's in five of the ten countries analysed (Finland, Germany, the Netherlands, Sweden, the United States). This is in line with the assumption that time availability generally has a minor impact on fathers' childcare participation.

Several tests for the robustness of the results have been carried out for all countries. For Germany, as an example, the results of this sensitivity analysis for fathers' childcare participation is displayed in table A2.1 in the appendix. As the literature suggests that predictors of fathers' childcare time are different on weekdays than on weekend days (Yeung et al. 2001), sensitivity analyses have been carried out, first using only diaries from weekdays and then only diaries from weekends. The results turn out to be very similar to the ones presented in table 1 . The only major difference is that the negative effect of the fathers' work status is slightly more pronounced in the regressions from weekday diaries, and vanishes for weekend dairies, concluding that time availability only plays a role for fathers' childcare participation on weekdays in some of the countries analysed. In addition, for those countries for which two or more diary days are available, fathers' average childcare participation per day in this time span

\footnotetext{
${ }^{8}$ Inclusion of all variables - father's work status, partner's work status, and interaction effects of both - is not possible in all countries due to multicollinearity issues. Especially the group of couples in which the partner works full-time or has unknown work hours, but the father not, is very small.
} 


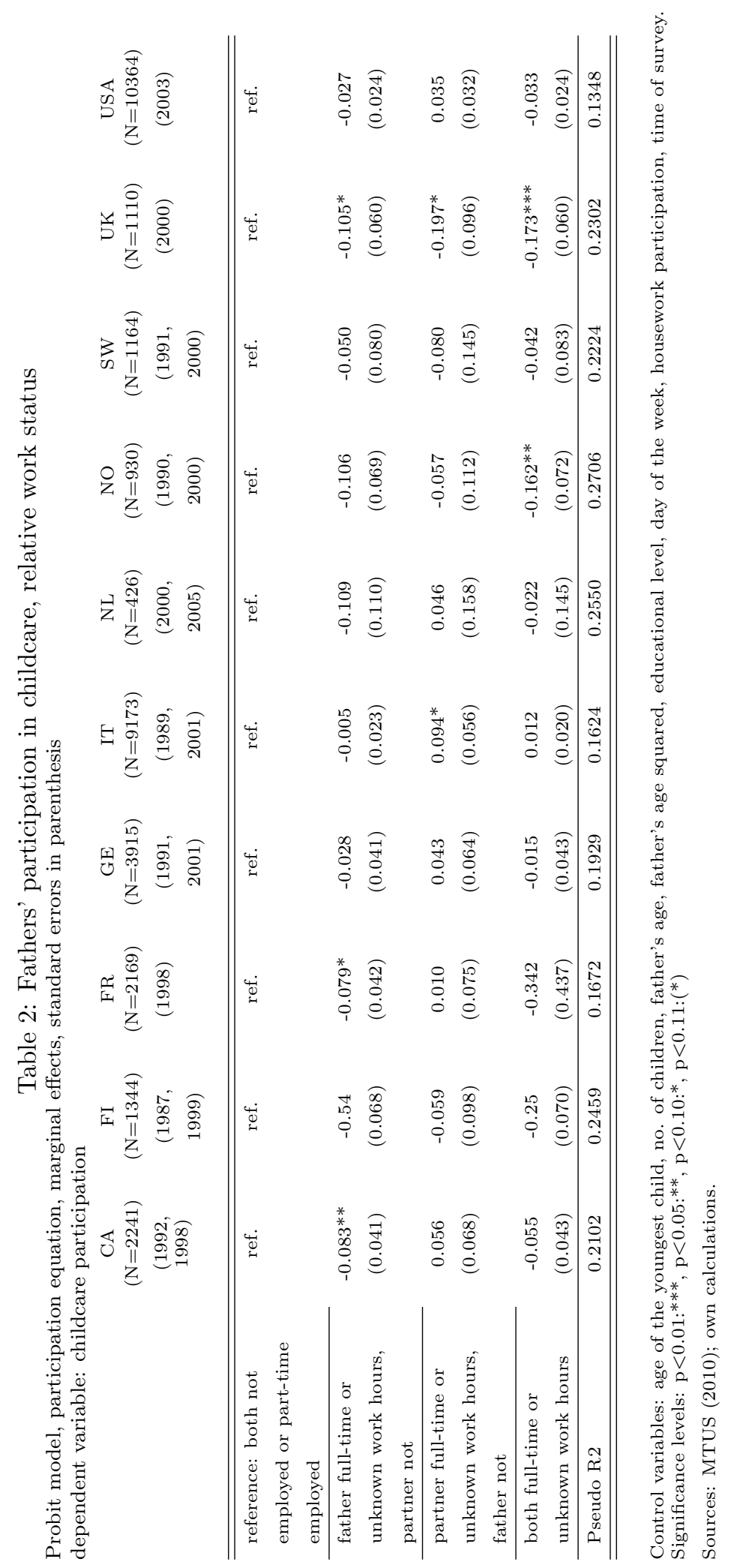


has been analysed as well, with negligible differences in the results compared to the analysis based on 24-hour diaries presented above.

For countries for which two surveys are available, one around 1990 and another around the year 2000, fathers' childcare participation has been estimated for each survey separately. ${ }^{9}$ The results for the earlier surveys are largely the same as those of the newer surveys, but two points are worth reporting. Firstly, the number of children is insignificant in Canada in 1992 and has a negative impact in Italy in 1989, but a positive impact in both countries in the more recent surveys. Secondly, in four countries (Finland, Germany, Italy, Sweden) the educational level has a strong effect on fathers' participation in childcare in the earlier survey, but not in the more recent survey.

\subsection{Time for childcare}

The results for the predictors of fathers' minutes spent on childcare per day are displayed in table 3 . The strongest positive effect on fathers' childcare time is the "weekend", and for all countries. On weekends, fathers spend between 11 minutes (Italy) and 30 minutes (Netherlands) more with their children than on weekdays. A positive correlation can also be found for the number of housework minutes in eight countries. Again, I refrain from interpreting this as a true causal relationship.

The number of children has a significant and positive impact only in Canada, Norway and the United States. With each additional child, fathers' childcare time rises between about 3 minutes in the United States and more than 8 minutes in Norway.

Contrary to the expectations derived from the results of other studies, the level of education does not have a universal impact on fathers' childcare time. Only in Italy and the United States do fathers with a medium level of education spend significantly more time with their children than those with low education, and in both countries as well as in France, Norway and the United Kingdom do fathers with high levels of education spend significantly more time with their children than their lesser-educated counterparts. The impact ranges between 13 minutes in the United states and 26 minutes in the United Kingdom. In other words, the father's educational level does not have an effect on fathers' childcare time in Canada, Finland, Germany, the Netherlands, and Sweden.

Full-time employment and employment with unknown work hours seem to be major obstacles for spending time with children in several countries. Full-time employment instead of no employment reduces childcare time in Germany (-16 minutes), Italy (-15 minutes), the United Kingdom (-57 minutes) and the United States (-39 minutes). Unknown work hours are correlated negatively with fathers' childcare time in Finland, Germany and Italy, but not in Canada, the Netherlands, and the United Kingdom (no data for Norway, Sweden, the United States).

\footnotetext{
${ }^{9}$ These estimates have been carried out for Canada, Finland, Germany, Italy, Norway and Sweden, but not for the Netherlands due to the small sample size.
} 
Table 3 (part I): Participating fathers' minutes of childcare OLS model, b-coefficients, standard errors in parenthesis dependent variable: minutes of childcare

\begin{tabular}{|c|c|c|c|c|c|c|}
\hline & & $\begin{array}{c}\mathrm{CA} \\
(\mathrm{N}=1115) \\
(1992 \\
1998)\end{array}$ & $\begin{array}{c}\text { FI } \\
(\mathrm{N}=580) \\
(1987 \\
1999)\end{array}$ & $\begin{array}{c}\mathrm{FR} \\
(\mathrm{N}=789) \\
(1998)\end{array}$ & $\begin{array}{c}\mathrm{GE} \\
(\mathrm{N}=2022) \\
(1991 \\
2001)\end{array}$ & $\begin{array}{c}\mathrm{IT} \\
(\mathrm{N}=3238) \\
(1989 \\
2001)\end{array}$ \\
\hline \multirow{3}{*}{$\begin{array}{l}\text { age of the youngest } \\
\text { child }\end{array}$} & $0-4$ & ref. & ref. & ref. & ref. & ref. \\
\hline & $5-12$ & $\begin{array}{c}-37.69^{* * *} \\
(6.25)\end{array}$ & $\begin{array}{c}-37.40^{* * *} \\
(6.528)\end{array}$ & $\begin{array}{c}-19.45^{* * *} \\
(4.74)\end{array}$ & $\begin{array}{c}-28.13^{* * *} \\
(3.47)\end{array}$ & $\begin{array}{c}-8.58^{* * *} \\
(3.13)\end{array}$ \\
\hline & $13-17$ & $\begin{array}{c}9.39 \\
(52.05)\end{array}$ & $\begin{array}{c}-55.80^{* * *} \\
(9.96)\end{array}$ & $\begin{array}{c}-23.88^{* * *} \\
(8.24)\end{array}$ & $\begin{array}{c}-36.94^{* * *} \\
(5.15)\end{array}$ & $\begin{array}{c}-28.00 * * * \\
(4.842)\end{array}$ \\
\hline no. of children & & $\begin{array}{l}7.90^{* *} \\
(3.90)\end{array}$ & $\begin{array}{l}-1.18 \\
(4.25)\end{array}$ & $\begin{array}{c}0.32 \\
(2.62)\end{array}$ & $\begin{array}{l}-1.21 \\
(2.24)\end{array}$ & $\begin{array}{c}1.11 \\
(1.82)\end{array}$ \\
\hline father's age & & $\begin{array}{l}-4.33 \\
(4.50)\end{array}$ & $\begin{array}{c}3.09 \\
(5.01)\end{array}$ & $\begin{array}{c}3.84 \\
(3.08)\end{array}$ & $\begin{array}{c}1.02 \\
(2.25)\end{array}$ & $\begin{array}{l}-1.51 \\
(2.34)\end{array}$ \\
\hline father's age squared & & $\begin{array}{c}0.05 \\
(0.06)\end{array}$ & $\begin{array}{l}-0.05 \\
(0.07)\end{array}$ & $\begin{array}{l}-0.05 \\
(0.04)\end{array}$ & $\begin{array}{l}-0.02 \\
(0.03)\end{array}$ & $\begin{array}{c}0.01 \\
(0.03)\end{array}$ \\
\hline \multirow[t]{2}{*}{ educational level } & $\begin{array}{l}\text { low } \\
\text { medium }\end{array}$ & $\begin{array}{c}\text { ref. } \\
-1.85 \\
(10.36)\end{array}$ & $\begin{array}{c}\text { ref. } \\
-0.10 \\
(7.30)\end{array}$ & $\begin{array}{c}\text { ref. } \\
8.462 \\
(6.65)\end{array}$ & $\begin{array}{c}\text { ref. } \\
-3.33 \\
(4.09)\end{array}$ & $\begin{array}{c}\text { ref. } \\
11.86^{* * *} \\
(3.81)\end{array}$ \\
\hline & high & $\begin{array}{c}9.91 \\
(9.05)\end{array}$ & $\begin{array}{l}13.03 \\
(8.38)\end{array}$ & $\begin{array}{c}15.16^{* *} \\
(6.64)\end{array}$ & $\begin{array}{c}1.47 \\
(3.83)\end{array}$ & $\begin{array}{c}19.70^{* * *} \\
(4.90)\end{array}$ \\
\hline \multirow[t]{3}{*}{ fathers' employment } & $\begin{array}{l}\text { not employed } \\
\text { part-time }\end{array}$ & $\begin{array}{c}\text { ref. } \\
-18.82 \\
(22.43)\end{array}$ & $\begin{array}{c}\text { ref. } \\
-21.47 \\
(24.20)\end{array}$ & $\begin{array}{c}\text { ref. } \\
-33.94^{* * *} \\
(12.89)\end{array}$ & $\begin{array}{c}\text { ref. } \\
-9.40 \\
(12.10)\end{array}$ & $\begin{array}{c}\text { ref. } \\
-9.07 \\
(11.13)\end{array}$ \\
\hline & full-time & $\begin{array}{c}-3.72 \\
(29.72)\end{array}$ & $\begin{array}{l}-20.72 \\
(16.47)\end{array}$ & $\begin{array}{c}-30.85^{* * *} \\
(9.67)\end{array}$ & $\begin{array}{c}-15.74^{* *} \\
(7.03)\end{array}$ & $\begin{array}{c}-14.65^{* *} \\
(7.03)\end{array}$ \\
\hline & $\begin{array}{l}\text { unknown work } \\
\text { hours }\end{array}$ & $\begin{array}{l}64.35^{*} \\
(35.09)\end{array}$ & $\begin{array}{l}-39.79 \\
(17.49)\end{array}$ & $\begin{array}{c}-39.78^{* * *} \\
(11.15)\end{array}$ & $\begin{array}{l}-28.31 \\
(21.91)\end{array}$ & $\begin{array}{c}-27.98^{* * *} \\
(7.69)\end{array}$ \\
\hline \multirow{4}{*}{$\begin{array}{l}\text { partner's } \\
\text { employment }\end{array}$} & not employed & ref. & ref. & ref. & ref. & ref. \\
\hline & part-time & $\begin{array}{c}6.99 \\
(13.09)\end{array}$ & - & $\begin{array}{l}-3.12 \\
(5.57)\end{array}$ & $\begin{array}{l}-2.56 \\
(3.47)\end{array}$ & $\begin{array}{l}-3.91 \\
(5.11)\end{array}$ \\
\hline & full-time & $\begin{array}{l}-2.38 \\
(6.94)\end{array}$ & - & $\begin{array}{c}3.87 \\
(5.62)\end{array}$ & $\begin{array}{l}-2.09 \\
(4.17)\end{array}$ & $\begin{array}{l}-5.22 \\
(3.82)\end{array}$ \\
\hline & $\begin{array}{l}\text { unknown work } \\
\text { hours }\end{array}$ & - & $\begin{array}{c}4.76 \\
(8.85)\end{array}$ & $\begin{array}{c}-10.60(*) \\
(6.46)\end{array}$ & $\begin{array}{l}-2.00 \\
(5.27)\end{array}$ & $\begin{array}{l}-3.35 \\
(5.93)\end{array}$ \\
\hline day of the week & $\begin{array}{l}\text { weekday } \\
\text { weekend }\end{array}$ & $\begin{array}{c}\text { ref. } \\
29.09 * * * \\
(8.50)\end{array}$ & $\begin{array}{c}\text { ref. } \\
23.62^{* * *} \\
(7.12)\end{array}$ & $\begin{array}{c}\text { ref. } \\
21.76^{* * *} \\
(5.53)\end{array}$ & $\begin{array}{c}\text { ref. } \\
23.83^{* * *} \\
(3.69)\end{array}$ & $\begin{array}{c}\text { ref. } \\
11.39^{* * *} \\
(2.29)\end{array}$ \\
\hline minutes of housework & & $\begin{array}{c}0.17^{* * *} \\
(0.06)\end{array}$ & $\begin{array}{l}0.12^{*} \\
(0.06)\end{array}$ & $\begin{array}{c}0.06 \\
(0.04)\end{array}$ & $\begin{array}{c}0.17^{* * *} \\
(0.03)\end{array}$ & $\begin{array}{c}0.11^{* * *} \\
(0.03)\end{array}$ \\
\hline time of survey & wave 1 & $\begin{array}{c}-11.77^{*} \\
(7.01)\end{array}$ & $\begin{array}{c}-23.21^{* *} \\
(9.72)\end{array}$ & - & $\begin{array}{c}-13.11^{* * *} \\
(3.74)\end{array}$ & $\begin{array}{l}-6.05 \\
(4.40)\end{array}$ \\
\hline constant & wave 2 & $\begin{array}{c}\text { ref. } \\
175.32^{* *} \\
(78.68)\end{array}$ & $\begin{array}{c}\text { ref. } \\
59.17 \\
(91.82) \\
\end{array}$ & $\begin{array}{c}- \\
15.22 \\
(56.09)\end{array}$ & $\begin{array}{c}\text { ref. } \\
78.08^{*} \\
(43.20) \\
\end{array}$ & $\begin{array}{c}\text { ref. } \\
122.41^{* * *} \\
(46.16)\end{array}$ \\
\hline R2 & & 0.1133 & 0.1504 & 0.1088 & 0.1250 & 0.0673 \\
\hline
\end{tabular}

Significance levels: $\mathrm{p}<0.01:^{* * *}, \mathrm{p}<0.05:^{* *}, \mathrm{p}<0.10:^{*}, \mathrm{p}<0.11:\left({ }^{*}\right)$

No dummy indicating survey years for the Netherlands due to the small sample size.

Sources: MTUS (2010); own calculations. 
Table 3 (continued): Participating fathers' minutes of childcare OLS model, b-coefficients, standard errors in parenthesis dependent variable: minutes of childcare

\begin{tabular}{|c|c|c|c|c|c|c|}
\hline & & $\begin{array}{c}\mathrm{NL} \\
(\mathrm{N}=222) \\
(2000 \\
2005)\end{array}$ & $\begin{array}{c}\mathrm{NO} \\
(\mathrm{N}=517) \\
(1990 \\
2000)\end{array}$ & $\begin{array}{c}\mathrm{SW} \\
(\mathrm{N}=693) \\
(1991 \\
2000)\end{array}$ & $\begin{array}{c}\mathrm{UK} \\
(\mathrm{N}=491) \\
(2000)\end{array}$ & $\begin{array}{c}\text { US } \\
(\mathrm{N}= \\
5668) \\
(2003)\end{array}$ \\
\hline \multirow{3}{*}{$\begin{array}{l}\text { age of the youngest } \\
\text { child }\end{array}$} & $0-4$ & ref. & ref. & ref. & ref. & ref. \\
\hline & $5-12$ & $\begin{array}{c}-31.61^{* * *} \\
(9.95)\end{array}$ & $\begin{array}{c}-28.60^{* * *} \\
(6.37)\end{array}$ & $\begin{array}{c}-28.43^{* * *} \\
(6.24)\end{array}$ & $\begin{array}{c}-41.96^{* * *} \\
(7.98)\end{array}$ & $\begin{array}{c}-34.86^{* * *} \\
(3.04)\end{array}$ \\
\hline & $13-17$ & $\begin{array}{l}-28.53 \\
(28.20)\end{array}$ & $\begin{array}{c}-38.78^{* * *} \\
(9.22)\end{array}$ & $\begin{array}{c}-33.07^{* * *} \\
(9.00)\end{array}$ & $\begin{array}{l}-30.39 * \\
(17.98)\end{array}$ & $\begin{array}{c}-67.06^{* * *} \\
(4.61)\end{array}$ \\
\hline no. of children & & $\begin{array}{c}6.92 \\
(7.95)\end{array}$ & $\begin{array}{l}8.31^{* *} \\
(3.87)\end{array}$ & $\begin{array}{c}2.12 \\
(2.93)\end{array}$ & $\begin{array}{l}-0.01 \\
(4.71)\end{array}$ & $\begin{array}{l}2.60^{*} \\
(1.50)\end{array}$ \\
\hline father's age & & $\begin{array}{c}0.57 \\
(6.63)\end{array}$ & $\begin{array}{l}-0.62 \\
(3.37)\end{array}$ & $\begin{array}{c}1.85 \\
(3.36)\end{array}$ & $\begin{array}{l}-0.77 \\
(4.98)\end{array}$ & $\begin{array}{l}3.55^{* *} \\
(1.74)\end{array}$ \\
\hline father's age squared & & $\begin{array}{l}-0.02 \\
(0.08)\end{array}$ & $\begin{array}{l}-0.00 \\
(0.04)\end{array}$ & $\begin{array}{l}-0.03 \\
(0.04)\end{array}$ & $\begin{array}{c}0.01 \\
(0.07)\end{array}$ & $\begin{array}{l}-0.04^{*} \\
(0.02)\end{array}$ \\
\hline \multirow[t]{2}{*}{ educational level } & $\begin{array}{l}\text { low } \\
\text { medium }\end{array}$ & $\begin{array}{c}\text { ref. } \\
2.14 \\
(12.66)\end{array}$ & $\begin{array}{c}\text { ref. } \\
13.15 \\
(9.57)\end{array}$ & $\begin{array}{c}\text { ref. } \\
0.49 \\
(6.63)\end{array}$ & $\begin{array}{c}\text { ref. } \\
9.01 \\
(9.64)\end{array}$ & $\begin{array}{c}\text { ref. } \\
14.13^{* *} \\
(6.47)\end{array}$ \\
\hline & high & $\begin{array}{c}8.59 \\
(11.68)\end{array}$ & $\begin{array}{l}17.09^{*} \\
(10.04)\end{array}$ & $\begin{array}{c}1.38 \\
(7.20)\end{array}$ & $\begin{array}{c}26.60^{* * *} \\
(9.34)\end{array}$ & $\begin{array}{c}13.22^{* *} \\
(5.93)\end{array}$ \\
\hline \multirow[t]{3}{*}{ fathers' employment } & $\begin{array}{l}\text { not employed } \\
\text { part-time }\end{array}$ & $\begin{array}{c}\text { ref. } \\
32.15 \\
(27.08)\end{array}$ & $\begin{array}{c}\text { ref. } \\
-3.83 \\
(16.00)\end{array}$ & $\begin{array}{c}\text { ref. } \\
5.74 \\
(15.85)\end{array}$ & $\begin{array}{c}\text { ref. } \\
-39.16 \\
(28.25)\end{array}$ & $\begin{array}{c}\text { ref. } \\
-13.88 \\
(10.02)\end{array}$ \\
\hline & full-time & $\begin{array}{c}-0.75 \\
(16.58)\end{array}$ & $\begin{array}{l}-13.81 \\
(11.96)\end{array}$ & $\begin{array}{l}-7.06 \\
(10.05)\end{array}$ & $\begin{array}{c}-57.24^{* * * *} \\
(21.15)\end{array}$ & $\begin{array}{c}-38.93^{* * *} \\
(6.37)\end{array}$ \\
\hline & $\begin{array}{l}\text { unknown work } \\
\text { hours }\end{array}$ & - & - & - & $\begin{array}{l}-12.01 \\
(10.13)\end{array}$ & - \\
\hline \multirow{4}{*}{$\begin{array}{l}\text { partner's } \\
\text { employment }\end{array}$} & not employed & ref. & ref. & ref. & ref. & ref. \\
\hline & part-time & $\begin{array}{c}5.11 \\
(10.14)\end{array}$ & $\begin{array}{l}-2.86 \\
(7.62)\end{array}$ & $\begin{array}{l}-13.08 \\
(8.28)\end{array}$ & $\begin{array}{l}-3.46 \\
(8.62)\end{array}$ & $\begin{array}{c}1.32 \\
(3.59)\end{array}$ \\
\hline & full-time & $\begin{array}{c}-2.01 \\
(14.72)\end{array}$ & $\begin{array}{c}4.65 \\
(8.42)\end{array}$ & $\begin{array}{l}-3.20 \\
(9.92)\end{array}$ & $\begin{array}{c}1.64 \\
(9.54)\end{array}$ & $\begin{array}{c}3.98 \\
(3.28)\end{array}$ \\
\hline & $\begin{array}{l}\text { unknown work } \\
\text { hours }\end{array}$ & - & - & - & & - \\
\hline day of the week & $\begin{array}{l}\text { weekday } \\
\text { weekend }\end{array}$ & $\begin{array}{c}\text { ref. } \\
29.98^{* * *} \\
(10.618)\end{array}$ & $\begin{array}{c}\text { ref. } \\
18.97^{* * *} \\
(7.01)\end{array}$ & $\begin{array}{c}\text { ref. } \\
20.29^{* * *} \\
(6.57)\end{array}$ & $\begin{array}{c}\text { ref. } \\
18.67^{* *} \\
(7.32)\end{array}$ & $\begin{array}{c}\text { ref. } \\
29.33^{* * *} \\
(2.96)\end{array}$ \\
\hline housework minutes & & $\begin{array}{c}0.44^{* * * *} \\
(0.10)\end{array}$ & $\begin{array}{c}0.15^{* * *} \\
(0.05)\end{array}$ & $\begin{array}{c}0.15^{* * *} \\
(0.06)\end{array}$ & $\begin{array}{c}0.08 \\
(0.05)\end{array}$ & $\begin{array}{l}0.04^{* *} \\
(0.02)\end{array}$ \\
\hline time of survey & wave 1 & - & $\begin{array}{l}15.07 \\
(6.08)\end{array}$ & $\begin{array}{c}6.27 \\
(5.65)\end{array}$ & - & - \\
\hline constant & wave 2 & $\begin{array}{c}- \\
50.61 \\
(123.87)\end{array}$ & $\begin{array}{c}\text { ref. } \\
77.91 \\
(62.92)\end{array}$ & $\begin{array}{c}\text { ref. } \\
41.84 \\
(64.83)\end{array}$ & $\begin{array}{c}- \\
144.96^{*} \\
(85.62)\end{array}$ & $\begin{array}{c}- \\
49.42 \\
(33.21)\end{array}$ \\
\hline R2 & & 0.2246 & 0.1372 & 0.1128 & 0.1409 & 0.0809 \\
\hline
\end{tabular}

Significance levels: $\mathrm{p}<0.01$ : $^{* *}, \mathrm{p}<0.05$ :** $^{* *} \mathrm{p}<0.10$ : $^{*}$

Sources: MTUS (2010); own calculations. 
Surprisingly, the female partner's employment status does not have an effect on fathers' childcare time in most of the countries analysed. Finally, among countries with surveys at several points in time, only Finland and Germany show a significant difference between the surveys. In these countries, fathers' childcare time is significantly higher around the turn of the millennium then ten years earlier. This is not the case in Canada, Italy, Norway or Sweden.

Again, models were re-estimated to include fathers' work status in relation to their partner's (table 4). Contrary to the results for childcare participation, the relative work status matters for fathers' childcare time in all countries but Sweden. In seven countries, fathers' minutes spent on childcare are significantly lower for couples in which only the father has a full-time job or has unknown work hours, compared to couples in which both work part-time or do not work at all (not in Canada, Finland, Sweden). Canadian and Finnish fathers report significantly more childcare minutes if only their partner works full-time or has unknown work hours, but their Dutch counterparts do significantly less childcare minutes in the same circumstances. Results are not significant in the other seven countries; this could be due to the low share of couples in this category. If both parents work full-time or have unknown work hours, fathers' childcare minutes are significantly lower in five countries, namely France, Germany, Italy, the United Kingdom and the United States. In sum, parents' relative work status does matter for fathers' childcare time in nine of the ten countries analysed.

Sensitivity analysis on the robustness of the results have been carried out for all countries, and the results for Germany as an example are reported in table A2.2 in the appendix. As the day of the week has a major influence on fathers' childcare time, it is worth analysing predictors separately for weekdays and weekends. Results for the impact of the employment status are similar to this variable's effect on fathers' participation: The employment status matters more on weekdays than it does on weekend days. Furthermore, while fathers' housework time is positively related to childcare time in the model presented above and in the regression for weekdays only, there is no significant correlation between them on weekends in any country besides Canada and the United States. In the former the positive relationship persists, while in the latter there is a negative relationship. One interpretation for this could be that fathers who spend a comparatively large amount of time with their children during the week are generally more inclined to do unpaid work at home, while fathers who are generally less involved in household chores use the spare time on the weekend to spend some of it with their children. The comparison of the results with those for the average number of childcare minutes of all diary days from the countries where more than one day is available does not reveal noticeable deviations from the results of the main model presented above.

In addition, for the six countries with two surveys and a sufficient sample size, it has been explored whether predictors of fathers' childcare minutes differ between two points in time in the same country. Similar to the results for fathers' childcare participation, the impact of the number of children has changed in Italy and Canada, from not significant in the first survey to a positive effect in the second survey; and the impact of the educational level was positive only in the first and not in the second survey in Finland, Italy and Sweden.

Finally, the model has been re-estimated using the Heckman (1979)2-step-selection model. ${ }^{10}$ The educational level was chosen as the selection variable, as it strongly affects fathers' childcare minutes, but impacts fathers' participation in childcare only in a few countries. The results for all independent

\footnotetext{
${ }^{10}$ The participation equation of the selection model is a Probit model, so that results for childcare participation are the same for both strategies.
} 


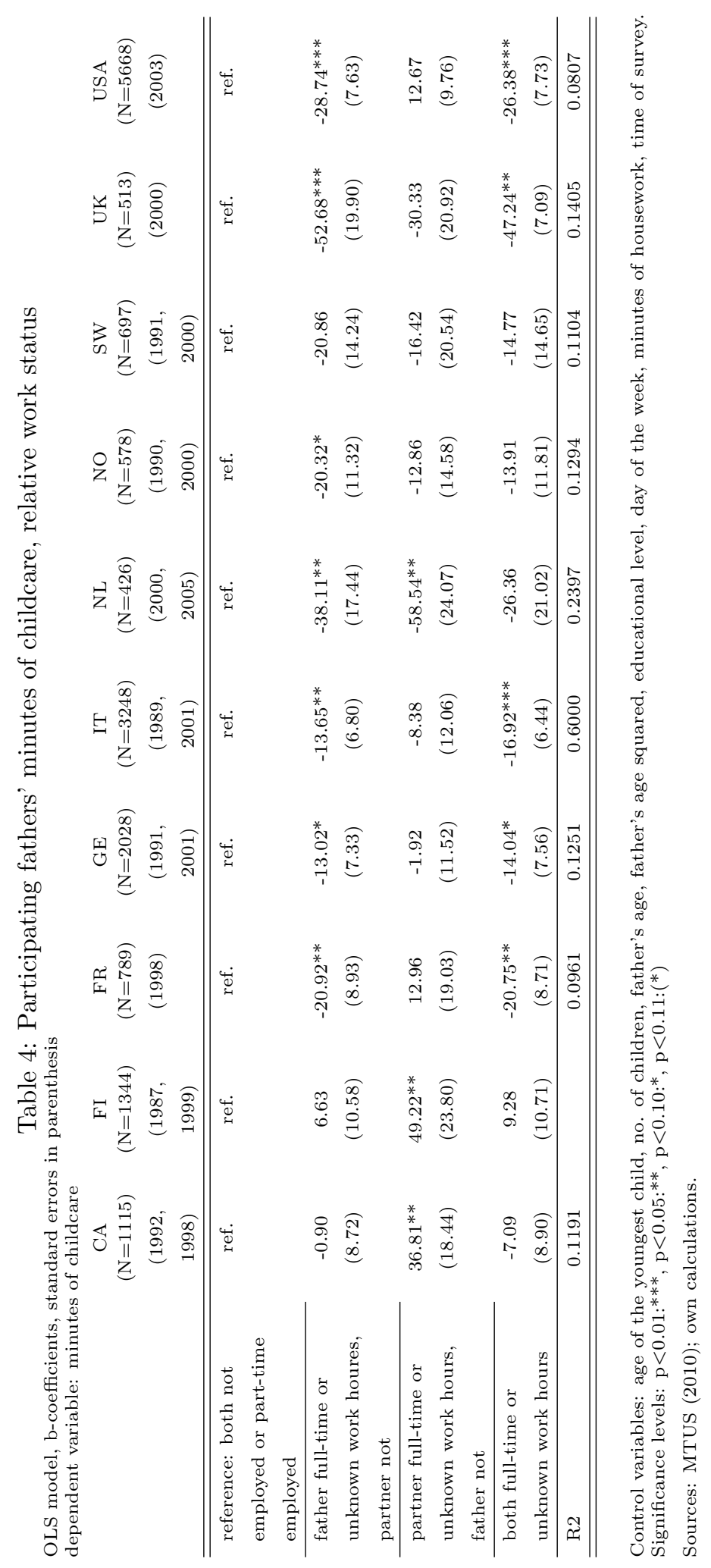


variables differ little from those of the OLS model presented above.

\section{Conclusion}

This paper deals with the difference between fathers' participation in childcare, defined as zero minutes of childcare on the survey day, and the amount of time participating fathers spend with their children, measured in minutes on the survey day. Time-use data from ten industrialised countries are used to assess cross-country differences. Changes over time are analysed for countries for which two surveys are available from the last 25 years.

Descriptive analysis reveals that participation and amount of time spent vary considerably between countries and survey years. In some countries, participation or the number of minutes have increased, while they have decreased in others. Moreover, countries exhibiting high participation rates do not necessarily show a large average number of minutes. While an increase in fathers participation rates can be interpreted as a sign towards higher gender equality in unpaid work, it remains unclear whether a decrease in their childcare time is a step backwards or just a result of the extension of public childcare facilities. In order to answer this question, the fathers' childcare time has to be analysed in relation to their spouses' which is not possible with the current data.

Regression results show that, firstly, predictors for both dependent variables differ between countries. For example, as to fathers' participation in childcare, the female partner's full-time employment (ref.: no employment) has a positive impact only in five of the ten countries analysed. Regarding participating fathers' childcare time, the number of children has a positive impact in Canada, Norway and the United States, but not in the other countries.

Secondly, the impact of certain variables varies over time, as sensitivity analysis revealed. For instance, the number of children has a positive impact on both dependent variables in Canada in 1998 and in Italy in 2001, but not in the earlier surveys from these countries. This could be interpreted as a decrease in the importance of gendered specialisation of childcare, as proposed by Becker's New Home Economics. Instead, an increase in the number of children and hence in the amount of childcare work seems to result in more engagement of fathers nowadays, at least in these two countries. In addition, the impact of the educational level on both fathers' participation and childcare minutes declined in several countries. Maybe less-educated fathers are catching up with highly educated fathers who were the forerunners of "modern" fatherhood.

Most important, predictors of fathers' childcare participation differ from predictors of participating fathers' childcare minutes. Results for the regression of fathers' participation in childcare show that, instead of variables indicating time availability (weekday/weekend day, work status, partner's work status, relative work status), the age of the youngest child, the fathers' educational level and his participation in housework are the main predictors. For this last variable, however, there are reasons for not interpreting this as a causal relationship, e.g. a fathers' general family-orientation could influence the dedication in both childcare and housework. Fathers' participation is affected by the total time children need care, which decreases as they become older. Several reasons might accout for the strong impact of the educational level. Highly educated fathers might be more aware of the positive impact of fathers' (and mothers') time with their children. This effect could also be interpreted as the prevalence of modern gender roles among highly educated fathers (Blossfeld and Drobnič 2001). 
The negative effect of the youngest child's age and the positive effect of the educational level are in line with the results of Pacholok and Gauthier (2010).

Regarding fathers' time with their children, time availability seems to play a major role, as fathers spend much more time with their children on weekend days than on weekdays. In addition, the employment status has an effect in several countries, also in comparison to their partner's. Given that the relative employment status reflects relative wages, the results support the Bargaining theory but not Becker's approach, as the relative work status has an effect on more or less childcare time, not on participation in childcare. The impact of the day of the week and the employment status is consistent with the findings of other studies using Tobit models to assess fathers' childcare time. However, the current analysis shows that the educational level does not have a major effect, in contrast to what previous studies using Tobit models suggest.

To sum up, apart from the negative effect of the youngest child's age, predictors for fathers' childcare participation and minutes are not the same. While both fathers' participation and amount of time depend on the children's needs, I conclude that participating in childcare is primarily driven by the educational level, whereas the amount of time they spend with their children depends on time

restrictions primarily set by their work hours. Consequently, these findings call for caution regarding the results of existing studies not distinguishing participation in childcare from participating fathers' childcare minutes.

\section{References}

Akerlof, G. A. and Kranton, R. E. (2000). Economics and identity, Quarterly Journal of Economics 115(3): 715-753.

Aldous, J., Mulligan, G. M. and Bjarnsson, T. (1998). Fathering over time: what makes the difference?, Journal of Marriage and the Family 60: 809-820.

Averett, S. L., Gennetian, L. A. and Peters, H. E. (2000). Patterns and determinants of parternal child care during a child's first theree years of life, Marriage and Family Review 29: 115-136.

Becker, G. S. (1965). A theory of the allocation of time, The Economic Journal 75(299): 493-517.

Becker, G. S. (1981). A treatise on the family, Havard University Press, Cambridge.

Becker, G. S. (1985). Human capital, effort, and the sexual division of labor, Journal of Labor Economics 3(2): 33-58.

Bianchi, S. (2000). Maternal emplyoment and time with children: dramatic change or surprising continuity?, Demography 37(4): 401-414.

Blossfeld, H.-P. and Drobnič, S. (2001). Theoretical perspectives on couples' careers, in H.-P. Blossfeld and S. Drobnič (eds), Careers of couples in contemporary societies: from male breadwinner to dualearner families, Oxford University Press, New York, pp. 16-50. 
Carlson, M. J. and McLanahan, S. S. (2004). Early father involvement in fragile families, in R. D.

Day and M. E. Lamb (eds), Conceptualizing and measuring father involvement, Erlbaum, Mahwa, pp. 241-270.

Cooksey, E. C. and Fondell, M. M. (1996). Spending time with his kids: effects of family structure on fathers' and childrens' lives, Journal of Marriage and the Family 58: 693-707.

Esping-Andersen, G. (1990). The three worlds of welfare capitalism, Princenton University Press, Princeton NJ.

Eurostat (2012). Female employment rate. [29 Jan. 2012].

URL: http://epp. eurostat.ec. europa. eu/portal/page/portal/statistics/search_ database

Galvez-Munoz, L., Rodriguez-Modrono, P. and Dominguez-Serrano, M. (2011). Work and time use by gender: A new clustering of european welfare systems, Feminist Economics 17(4): 125-157.

Gauthier, A. H., Smeeding, T. M. and Furstenberg, F. F. (2004). Do we invest less time in children? trends in parental time in selected industrialized countries since the 1960's, Center fopr Policy Research Paper $\mathbf{9 9 .}$

Gauthier, A. and Hatzius, J. (1997). Family benefits and fertility: An econometric analysis, Population Studies 51: 295-306.

Gershuny, J. and Sullivan, O. (2003). Time use, gender, and public policy regimes, Social Politics 10(2): 205-228.

Gornick, J. C. and Meyers, M. K. (2004). Welfare regimes in relation to paid work and care, in J. Z. Giele and E. Holst (eds), Changing life patterns in Western industrial societies, Elsevier Science Press, pp. 45-67.

Gottmann, J. M. (1994). What predicts divorce? The relationship between marital processes and marital outcomes, Erlbaum, Hillsdale, NJ.

Haas, L. and Hwang, C. P. (2008). The impact of taking parental leave on fathers' participation in childcare and relationships with children: lessons from Sweden, Community, Work and Family 11(1): 85-104.

Heckman, J. J. (1979). Sample selection bias as a specification error, Econometrica 47: 153-161.

Hook, J. L. (2006). Care in context: men's unpaid work in 20 countries, 1965-2003, American Sociological Review $\mathbf{7 1 .}$

Hook, J. L. (2010). Gender inequality in the welfare state: sex segregation in housework, 1965-2003, American Journal of Sociology 115(5): 1480-1523.

Ishii-Kuntz, M. and Coltrane, S. (1992). Predicting the sharing of household labor: are parenting and housework distinct?, Sociological Perspectives 35: 629-647. 
Jones, B. (2009). Logit and probit. [29 Jan. 2012].

URL: http://psfaculty. ucdavis. edu/bsjjones/binaryresponse. pdf

Kalenkoski, C. M. and Foster, G. (2008). The quality of time spent with children in australian households, Review of Economics of the Household 6: 243-266.

Kitterod, R. H. and Petterson, S. V. (2006). Making up for mothers' employment working hours? Housework and childcare among Norwegian fathers, Work, Employment and Society 20(3): 473492.

Korpi, W. (2000). Faces of inequalities: gender, class and patterns of inequalities in differenct types of welfare states, Social Politics 7(1): 127-191.

Marsiglio, W. (1991). Paternal engagement activities with minor children, Journal of Marriage and Family 53: 973-987.

Merz, M. (2004). Women's hours of market work in Germany: The role of parental leave, IZA Discussion Paper (128).

Mischke, M. (2011). Types of public family support: a cluster analysis of 15 European countries, Journal of Comparative Policy Analysis: Research and Practice 13(4): 443-456.

Moss, P. and Wall, K. (eds) (2007). International Review of Leave Policies and Related Research 2007, number 80 in Employment Relations Research Series, EMAR Employment Market Analysis and Research.

MTUS (2010). Multinational time use study versions world 5.52, 5.53, 5.58. created by Jonathan Gershuny and Kimberly Fisher, with Evrim Altintas, Alyssa Borkosky, Anita Bortnik, Donna Dosman, Cara Fedick, Tyler Frederick, Anne H. Gauthier, Sally Jones, Jiweon Jun, Aaron Lai, Qianhan Lin, Tingting Lu, Fiona Lui, Leslie MacRae, Berenice Monna, José Ignacio Giménez Nadal, Monica Pauls, Cori Pawlak, Andrew Shipley, Cecilia Tinonin, Nuno Torres, Charlemaigne Victorino, and Oiching Yeung. Centre for Time Use Research, University of Oxford, United Kingdom.

Ott, N. (1992). Intrafamily Bargaining and Household Decisions, Berlin.

Pacholok, S. and Gauthier, A. (2010). Non-participant fathers in time-use studies: uninvolved or data artifact?, Social Indicators Research 96: 249-266.

Palkovitz, R. (2002). Involved fathering and child development: advancing our understanding of good fathering, in C. S. Tamis-LeMonda and N. Canbrera (eds), Handbook of father involvement: multidisciplinary perspectives, Erlbaum Mahwah, pp. 141-167.

Pleck, J. H. (2007). Why could father involvement benefit children? theoretical perspectives, Applied Development Science 11(4): 196-202.

Reich, N., Boll, C. and Leppin, J. (2012). Fathers' childcare and parental leave policies: evidence from western european countries and canada, unpublished pp. 1-25.

Romano, M. C. and Bruzzese, D. (2007). Fathers' participation in the domestic activities of everyday life, Social Indicators Research 84: 97-116. 
Sayer, L. C., Bianchi, S. M. and Robinson, J. P. (2004). Are parents investing less in children? trends in mothers' and fathers' time with children, American Journal of Sociology 110: 1-43.

Sayer, L. C., Gauthier, A. H. and Furstenberg, F. F. (2004). Educational differences in parents' time with children: cross-national variations, Journal of Marriage and Family 66(5): 1152-1169.

Snarey, J. (1993). How fathers care for the next generation, Havard University Press, Cambridge, MA.

Stancanelli, E. (2003). Do fathers care?, OFCE Working Paper (8).

Stewart, J. (2009). Tobit or not tobit?, IZA Discussion Paper 4588: 1-24.

Sullivan, O., Coltrane, S., McAnally, L. and Altintas, E. (2009). Father-friendly policies and time-use data in a cross-national context: potential and prospects for future research, The Annals of the American Academy of Policital and Social Sciences 624(1): 234-254.

Volling, B. L. and Belsky, J. (1991). Multiple determinants of father involvement during infacny in dual-earner and soingle-earner families, Journal of Marriage and Family 53: 461-474.

Wang, R. and Bianchi, S. M. (2009). ATUS fathers' involvement in childcare, Social Indicators Research 93: $141-145$.

West, C. and Zimmermann, D. H. (1987). Doing gender, Gender and Society 1: 125-151.

Yeung, W. J., Sandberg, J. F., Davis-Kean, P. E. and Hofferth, S. L. (2001). Children's time with fathers in intact families, Journal of Marriage and Family 63: 136-154. 


\title{
Appendix A1
}

\author{
Summary Statistics
}

Table A1.1: Canada

\begin{tabular}{lcccc|cccc} 
Canada & \multicolumn{3}{c|}{ all fathers $(\mathrm{N}=2241)$} & \multicolumn{3}{c}{ participating fathers (N=1115) } \\
& mean & std. dev. & $\min$ & $\max$ & mean & std. dev. & min & max \\
\hline \hline childcare participation & 0.49 & 0.50 & 0 & 1 & 1 & 0 & 1 & 1 \\
childcare minutes & 48.40 & 76.96 & 0 & 660 & 98.33 & 84.41 & 5 & 660 \\
age of the youngest & 1.70 & 0.71 & 1 & 3 & 1.39 & 0.53 & 1 & 3 \\
child & & & & & & & & \\
no. of children & 1.94 & 0.84 & 1 & 6 & 2.00 & 0.85 & 1 & 6 \\
father's age & 37.72 & 6.93 & 20 & 55 & 35.80 & 6.29 & 20 & 55 \\
father's age squared & 1470 & 530 & 400 & 3025 & 1321 & 461 & 400 & 3025 \\
educational level & 2.39 & 0.79 & 1 & 3 & 2.51 & 0.72 & 1 & 3 \\
fathers' employment & 1.35 & 0.04 & 1 & 4 & 1.39 & 0.98 & 1 & 4 \\
partner's employment & 2.42 & 1.39 & 1 & 4 & 2.49 & 0.53 & 1 & 4 \\
weekend & 0.29 & 0.46 & 0 & 1 & 0.29 & 0.45 & 0 & 1 \\
housework participation & 0.64 & 0.48 & 0 & 1 & 0.75 & 0.43 & 0 & 1 \\
minutes of housework & 48.05 & 73.85 & 0 & 600 & 60.48 & 77.33 & 0 & 480 \\
older survey & 0.48 & 0.50 & 0 & 1 & 0.46 & 0.50 & 0 & 1 \\
\hline \hline
\end{tabular}

Definition of variables: childcare participation: 0 minutes $=$ no $=0,>0$ minutes $=$ yes $=1$; childcare minutes: minutes of childcare (MTUS activity code av11) on the survey day); age of the youngest child: $1: 0-4,2: 5-12,3: 13-17$; number of children: number of children under the age of 18 in the family; father's age: age of the father in years; father's age squared: square of the age of the father; educational level: 1: low (below ISCED 3.), 2: medium (ISCED 3 or 4), 3: high (ISCED 5 or higher); father's employment: fathers general work status, 1: full-time employment, 2: part-time employment, 3: unknown work hours, 4: not employed; partner's employment: female partner's general work status, 1: full-time employment, 2: part-time employment, 3: unknown work hours, 4: not employed; weekend: survey on a weekday $(=0)$ or weekend $(=1)$; housework participation: participation in housework (MTUS activity codes av6 and av7) on the survey day, yes=1, no=0; minutes of housework: minutes of housework (sum of minutes of activity codes av6 + av7) on the survey day; time of the survey: dummy for 1st (earlier) survey if 2 surveys are available.

Sources: MTUS (2010); own calculations. 
Table A1.2 Finland

\begin{tabular}{lcccc|cccc} 
Finland & \multicolumn{3}{c|}{ all fathers $(\mathrm{N}=1344)$} & \multicolumn{3}{c}{ participating fathers (N=580) } \\
& mean & std. dev. & $\min$ & $\max$ & mean & std. dev. & min & max \\
\hline \hline childcare participation & 0.44 & 0.50 & 0 & 1 & 1 & 0 & 1 & 1 \\
childcare minutes & 32.06 & 60.31 & 0 & 420 & 73.24 & 72.78 & 10 & 420 \\
age of the youngest & 1.80 & 0.75 & 1 & 3 & 1.38 & 0.56 & 1 & 3 \\
child & & & & & & & & \\
no. of children & 1.79 & 0.84 & 1 & 8 & 1.93 & 0.89 & 1 & 8 \\
father's age & 39.00 & 7.18 & 21 & 55 & 35.97 & 6.60 & 22 & 55 \\
father's age squared & 1572 & 565 & 441 & 3025 & 1337 & 495 & 484 & 3025 \\
educational level & 1.60 & 0.79 & 1 & 3 & 1.72 & 0.79 & 1 & 3 \\
fathers' employment & 1.41 & 0.91 & 1 & 4 & 1.40 & 0.90 & 1 & 4 \\
partner's employment & 3.17 & 0.38 & 1 & 4 & 3.21 & 0.41 & 3 & 4 \\
weekend & 0.35 & 0.48 & 0 & 1 & 0.35 & 0.48 & 0 & 1 \\
housework participation & 0.71 & 0.46 & 0 & 1 & 0.78 & 0.42 & 0 & 1 \\
minutes of housework & 37.14 & 50.04 & 0 & 360 & 44.22 & 52.58 & 0 & 330 \\
older survey & .62 & 0.49 & 0 & 1 & 0.60 & 0.49 & 0 & 1 \\
\hline \hline
\end{tabular}

Definition of variables: see table A1.1.

Sources: MTUS (2010); own calculations.

Table A1.3: France

\begin{tabular}{lcccc|cccc} 
France & \multicolumn{3}{c|}{ all fathers (N=2169) } & \multicolumn{3}{c}{ participating fathers (N=789) } \\
& mean & std. dev. & $\min$ & $\max$ & mean & std. dev. & min & max \\
\hline \hline childcare participation & 0.36 & 0.48 & 0 & 1 & 1 & 0 & 1 & 1 \\
childcare minutes & 24.25 & 48.07 & 0 & 370 & 66.65 & 59.39 & 10 & 370 \\
age of the youngest & 1.85 & 0.675 & 1 & 3 & 1.47 & 0.61 & 1 & 3 \\
child & & & & & & & & \\
no. of children & 1.84 & 0.92 & 1 & 10 & 1.92 & 0.92 & 1 & 10 \\
father's age & 39.62 & 7.05 & 20 & 55 & 37.04 & 6.54 & 22 & 55 \\
father's age squared & 1619 & 561 & 400 & 3025 & 1415 & 511 & 484 & 3025 \\
educational level & 2.19 & 0.67 & 1 & 3 & 2.30 & 0.67 & 1 & 3 \\
fathers' employment & 1.57 & 1.01 & 1 & 4 & 1.55 & 1.03 & 1 & 4 \\
partner's employment & 2.44 & 1.26 & 1 & 4 & 2.39 & 1.26 & 1 & 4 \\
weekend & 0.28 & 0.45 & 0 & 1 & 0.28 & 0.45 & 0 & 1 \\
housework participation & 0.52 & 0.50 & 0 & 1 & 0.66 & 0.47 & 0 & 1 \\
minutes of housework & 32.25 & 52.31 & 0 & 460 & 43.11 & 55.49 & 0 & 410 \\
\hline \hline
\end{tabular}

Definition of variables: see table A1.1.

Sources: MTUS (2010); own calculations. 
Table A1.4: Germany

\begin{tabular}{lcccc|cccc} 
Germany & \multicolumn{3}{c|}{ all fathers (N=3915) } & \multicolumn{3}{c}{ participating fathers (N=2022) } \\
& mean & std. dev. & $\min$ & $\max$ & mean & std. dev. & min & max \\
\hline \hline childcare participation & 0.52 & 0.50 & 0 & 1 & 1 & 0 & 1 & 1 \\
childcare minutes & 34.18 & 56.97 & 0 & 575 & 66.06 & 64.55 & 5 & 575 \\
age of the youngest & 1.89 & 0.78 & 1 & 3 & 1.54 & 0.65 & 1 & 3 \\
child & & & & & & & & \\
no. of children & 1.73 & 0.81 & 1 & 6 & 1.80 & 0.84 & 1 & 5 \\
father's age & 40.40 & 6.60 & 20 & 55 & 38.48 & 6.34 & 22 & 55 \\
father's age squared & 1675 & 533 & 400 & 3025 & 1512 & 497 & 484 & 3025 \\
educational level & 2.13 & 0.80 & 1 & 3 & 2.17 & 0.81 & 1 & 3 \\
fathers' employment & 1.21 & 0.72 & 1 & 4 & 1.22 & 0.74 & 1 & 4 \\
partner's employment & 2.50 & 1.16 & 1 & 4 & 2.55 & 1.17 & 1 & 4 \\
weekend & 0.29 & 0.46 & 0 & 1 & 0.30 & 0.46 & 0 & 1 \\
housework participation & 0.70 & 0.46 & 0 & 1 & 0.79 & 0.41 & 0 & 1 \\
minutes of housework & 37.63 & 51.68 & 0 & 470 & 44.60 & 53.49 & 0 & 330 \\
older survey & 0.57 & 0.49 & 0 & 1 & 0.60 & 0.49 & 0 & 1 \\
\hline \hline
\end{tabular}

Definition of variables: see table A1.1.

Sources: MTUS (2010); own calculations.

Table A1.5: Italy

\begin{tabular}{lcccc|cccc} 
Italy & \multicolumn{3}{c|}{ all fathers (N=9173) } & \multicolumn{3}{c}{ participating fathers (N=3238) } \\
& mean & std. dev. & $\min$ & $\max$ & mean & std. dev. & min & max \\
\hline \hline childcare participation & 0.35 & 0.48 & 0 & 1 & 1 & 0 & 1 & 1 \\
childcare minutes & 25.34 & 51.77 & 0 & 580 & 71.74 & 65.28 & 1 & 580 \\
age of the youngest & 2.07 & 0.67 & 1 & 3 & 1.77 & 0.60 & 1 & 3 \\
child & & & & & & & & \\
no. of children & 1.63 & 0.870 & 1 & 8 & 1.71 & 0.70 & 1 & 7 \\
father's age & 41.56 & 6.50 & 20 & 55 & 369.33 & 5.96 & 21 & 55 \\
father's age squared & 1769 & 540 & 400 & 3025 & 1582 & 479 & 441 & 3025 \\
educational level & 1.69 & 0.62 & 1 & 3 & 1.86 & 0.60 & 1 & 3 \\
fathers' employment & 1.51 & 0.94 & 1 & 4 & 1.50 & 0.93 & 1 & 4 \\
partner's employment & 2.01 & 1.30 & 1 & 4 & 2.08 & 1.30 & 1 & 4 \\
weekend & 0.66 & 0.48 & 0 & 1 & 0.66 & 0.47 & 0 & 1 \\
housework participation & 0.39 & 0.49 & 0 & 1 & 0.53 & 0.50 & 0 & 1 \\
minutes of housework & 23.94 & 51.06 & 0 & 740 & 33.88 & 58.19 & 0 & 740 \\
older survey & 0.49 & 0.50 & 0 & 1 & 0.39 & 0.49 & 0 & 1 \\
\hline \hline
\end{tabular}

Definition of variables: see table A1.1.

Sources: MTUS (2010); own calculations. 
Table A1.6: Netherlands

\begin{tabular}{lllll|cccc} 
Netherlands & \multicolumn{3}{c|}{ all fathers $(\mathrm{N}=426)$} & \multicolumn{3}{c}{ participating fathers (N=222) } \\
& mean & std. dev. & $\min$ & $\max$ & mean & std. dev. & min & max \\
\hline \hline childcare participation & 0.52 & 0.50 & 0 & 1 & 1 & 0 & 1 & 1 \\
childcare minutes & 43.00 & 64.88 & 0 & 405 & 82.17 & 69.48 & 15 & 405 \\
age of the youngest & 1.73 & 0.73 & 1 & 3 & 1.40 & 0.55 & 1 & 3 \\
child & & & & & & & & \\
no. of children & 1.95 & 0.82 & 1 & 5 & 2.05 & 0.80 & 1 & 5 \\
father's age & 40.47 & 6.43 & 20 & 55 & 38.40 & 5.96 & 20 & 55 \\
father's age squared & 17679 & 522 & 400 & 3025 & 1510 & 465 & 400 & 3025 \\
educational level & 2.28 & 0.674 & 1 & 3 & 2.38 & 0.72 & 1 & 3 \\
fathers' employment & 1.28 & 0.82 & 1 & 4 & 1.33 & 0.88 & 1 & 4 \\
partner's employment & 2.57 & 1.07 & 1 & 4 & 2.48 & 1.08 & 1 & 4 \\
weekend & 0.31 & 0.46 & 0 & 1 & 0.33 & 0.47 & 0 & 1 \\
housework participation & 0.61 & 0.49 & 0 & 1 & 0.73 & 0.45 & 0 & 1 \\
minutes of housework & 36.76 & 47.94 & 0 & 300 & 45.47 & 49.20 & 0 & 270 \\
\hline \hline
\end{tabular}

Definition of variables: see table A1.1.

Sources: MTUS (2010); own calculations.

Table A1.7: Norway

\begin{tabular}{lcccc|cccc} 
Norway & \multicolumn{4}{c|}{ all fathers $(\mathrm{N}=930)$} & \multicolumn{3}{c}{ participating fathers (N=578) } \\
& mean & std. dev. & min & max & mean & std. dev. & min & max \\
\hline \hline childcare participation & 0.56 & 0.50 & 0 & 1 & 1 & 0 & 1 & 1 \\
childcare minutes & 45.10 & 64.64 & 0 & 465 & 80.42 & 67.90 & 10 & 465 \\
age of the youngest & 1.73 & 0.78 & 1 & 3 & 1.35 & 0.57 & 1 & 3 \\
child & & & & & & & & \\
no. of children & 1.88 & 0.85 & 1 & 5 & 2.03 & 0.86 & 1 & 5 \\
father's age & 38.78 & 7.38 & 22 & 55 & 36.19 & 6.74 & 22 & 55 \\
father's age squared & 1559 & 581 & 484 & 3025 & 1355 & 510 & 484 & 3025 \\
educational level & 2.24 & 0.62 & 1 & 3 & 2.28 & 0.61 & 1 & 3 \\
fathers' employment & 1.25 & 0.77 & 1 & 4 & 1.24 & 0.75 & 1 & 4 \\
partner's employment & 2.00 & 1.09 & 1 & 4 & 2.11 & 1.12 & 1 & 4 \\
weekend & 0.31 & 0.546 & 0 & 1 & 0.31 & 0.46 & 0 & 1 \\
housework participation & 0.77 & 0.42 & 0 & 1 & 0.84 & 0.37 & 0 & 1 \\
minutes of housework & 58.68 & 73.73 & 0 & 680 & 62.96 & 67.82 & 0 & 500 \\
older survey & 0.43 & 0.50 & 0 & 1 & 0.43 & 0.50 & 0 & 1 \\
\hline \hline
\end{tabular}

Definition of variables: see table A1.1.

Sources: MTUS (2010); own calculations. 
Table A1.8: Sweden

\begin{tabular}{lcccc|cccc} 
Sweden & \multicolumn{3}{c|}{ all fathers $(\mathrm{N}=1164)$} & \multicolumn{3}{c}{ participating fathers (N=693) } \\
& mean & std. dev. & $\min$ & $\max$ & mean & std. dev. & min & max \\
\hline \hline childcare participation & 0.60 & 0.49 & 0 & 1 & 1 & 0 & 1 & 1 \\
childcare minutes & 45.91 & 67.42 & 0 & 600 & 77.04 & 72.32 & 10 & 600 \\
age of the youngest & 1.62 & 0.76 & 1 & 3 & 1.31 & 0.57 & 1 & 3 \\
child & & & & & & & & \\
no. of children & 1.91 & 0.88 & 1 & 6 & 2.03 & 0.90 & 1 & 6 \\
father's age & 39.34 & 7.20 & 21 & 55 & 37.41 & 6.72 & 21 & 55 \\
father's age squared & 1599 & 568 & 441 & 3025 & 1444 & 513 & 441 & 3025 \\
educational level & 2.02 & 0.75 & 1 & 3 & 2.11 & 0.73 & 1 & 3 \\
fathers' employment & 1.30 & 0.78 & 1 & 4 & 1.28 & 0.78 & 1 & 4 \\
partner's employment & 2.00 & 1.07 & 1 & 4 & 2.08 & 1.08 & 1 & 4 \\
weekend & 0.48 & 0.50 & 0 & 1 & 0.47 & 0.50 & 0 & 1 \\
housework participation & 0.79 & 0.41 & 0 & 1 & 0.84 & 0.37 & 0 & 1 \\
minutes of housework & 55.69 & 64.87 & 0 & 420 & 62.12 & 67.60 & 0 & 420 \\
older survey & 0.55 & 0.50 & 0 & 1 & 0.55 & 0.50 & 0 & 1 \\
\hline \hline
\end{tabular}

Definition of variables: see table A1.1.

Sources: MTUS (2010); own calculations.

Table A1.9: United Kingdom

\begin{tabular}{lcccc|cccc} 
United Kingdom & \multicolumn{3}{c|}{ all fathers $(\mathrm{N}=1110)$} & \multicolumn{3}{c}{ participating fathers (N=491) } \\
& mean & std. dev. & $\min$ & $\max$ & mean & std. dev. & min & max \\
\hline \hline childcare participation & 0.46 & 0.50 & 0 & 1 & 1 & 0 & 1 & 1 \\
childcare minutes & 37.98 & 66.68 & 0 & 500 & 82.77 & 77.36 & 10 & 500 \\
age of the youngest & 1.81 & 0.74 & 1 & 3 & 1.42 & 0.55 & 1 & 3 \\
child & & & & & & & & \\
no. of children & 1.89 & 0.90 & 1 & 6 & 1.96 & 0.976 & 1 & 6 \\
father's age & 39.18 & 7.50 & 20 & 55 & 36.93 & 7.08 & 20 & 55 \\
father's age squared & 1593 & 598 & 400 & 3025 & 1414 & 538 & 400 & 3025 \\
educational level & 1.94 & 0.77 & 1 & 3 & 1.97 & 0.76 & 1 & 3 \\
fathers' employment & 1.29 & 0.85 & 1 & 4 & 1.30 & 0.87 & 1 & 4 \\
partner's employment & 2.31 & 1.18 & 1 & 4 & 2.48 & 1.17 & 1 & 4 \\
weekend & 0.50 & 0.50 & 0 & 1 & 0.52 & 0.50 & 0 & 1 \\
housework participation & 0.78 & 0.41 & 0 & 1 & 0.87 & 0.34 & 0 & 1 \\
minutes of housework & 60.72 & 75.75 & 0 & 540 & 74.40 & 85.23 & 0 & 540 \\
\hline \hline
\end{tabular}

Definition of variables: see table A1.1.

Sources: MTUS (2010); own calculations. 
Table A1.10: United States

\begin{tabular}{lcccc|cccc} 
United States & \multicolumn{3}{c|}{ all fathers (N=10364) } & \multicolumn{3}{c}{ participating fathers (N=5668) } \\
& mean & std. dev. & $\min$ & $\max$ & mean & std. dev. & min & max \\
\hline \hline childcare participation & 0.55 & 0.50 & 0 & 1 & 1 & 0 & 1 & 1 \\
childcare minutes & 57.27 & 93.50 & 0 & 870 & 103.27 & 104.95 & 1 & 870 \\
age of the youngest & 1.70 & 0.72 & 1 & 3 & 1.51 & 0.62 & 1 & 3 \\
child & & & & & & & & \\
no. of children & 1.97 & 0.95 & 1 & 9 & 2.08 & 0.97 & 1 & 9 \\
father's age & 39.33 & 7.54 & 20 & 55 & 38.45 & 7.11 & 20 & 55 \\
father's age squared & 1603 & 592 & 440 & 3025 & 1529 & 553 & 400 & 3025 \\
educational level & 2.55 & 0.66 & 1 & 3 & 2.66 & 0.59 & 1 & 3 \\
fathers' employment & 1.24 & 0.77 & 1 & 4 & 1.25 & 0.79 & 1 & 4 \\
partner's employment & 2.23 & 1.32 & 1 & 4 & 2.23 & 1.30 & 1 & 4 \\
weekend & 0.51 & 0.50 & 0 & 1 & 0.47 & 0.50 & 0 & 1 \\
housework participation & 0.52 & 0.50 & 0 & 1 & 0.61 & 0.349 & 0 & 1 \\
minutes of housework & 49.29 & 89.95 & 0 & 800 & 54.90 & 87.82 & 0 & 717 \\
\hline \hline
\end{tabular}

Definition of variables: see table A1.1.

Sources: MTUS (2010); own calculations. 


\section{Appendix A2}

Sensitivity Analysis: Germany as an example 
Table A2.1: Fathers' participation in childcare in Germany - sensitivity analysis

Probit model, dependent variable: childcare participation. Results as marginal effects, standard errors in parenthesis.

\begin{tabular}{|c|c|c|c|c|c|c|}
\hline & & $\begin{array}{l}\text { only } 1991 \\
(\mathrm{~N}=2245)\end{array}$ & $\begin{array}{l}\text { only } 2001 \\
(\mathrm{~N}=1670)\end{array}$ & $\begin{array}{l}\text { participation } \\
\text { on } 2 \text { days } \\
(\mathrm{N}=2334)\end{array}$ & $\begin{array}{c}\text { only } \\
\text { week-days } \\
(\mathrm{N}=2769)\end{array}$ & $\begin{array}{c}\text { only } \\
\text { weekend- } \\
\text { days } \\
(\mathrm{N}=1146)\end{array}$ \\
\hline \multirow{3}{*}{$\begin{array}{l}\text { age of the youngest } \\
\text { child }\end{array}$} & $0-4$ & ref. & ref. & ref. & ref. & ref. \\
\hline & $5-12$ & $\begin{array}{c}-0.238^{* * *} \\
(0.028)\end{array}$ & $\begin{array}{c}-0.317^{* * *} \\
(0.034)\end{array}$ & $\begin{array}{c}-0.265^{* * *} \\
(0.022)\end{array}$ & $\begin{array}{c}-0.259^{* * *} \\
(0.025)\end{array}$ & $\begin{array}{c}-0.308^{* * *} \\
(0.040)\end{array}$ \\
\hline & $13-17$ & $\begin{array}{c}-0.505^{* * *} \\
(0.027)\end{array}$ & $\begin{array}{c}-0.575^{* * *} \\
(0.026)\end{array}$ & $\begin{array}{c}-0.625^{* * *} \\
(0.022)\end{array}$ & $\begin{array}{c}-0.533^{* * *} \\
(0.022)\end{array}$ & $\begin{array}{c}-0.571^{* * *} \\
(0.034)\end{array}$ \\
\hline \multicolumn{2}{|l|}{ no. of children } & $\begin{array}{c}0.006 \\
(0.015)\end{array}$ & $\begin{array}{l}-0.031 \\
(0.020)\end{array}$ & $\begin{array}{c}0.001 \\
(0.013)\end{array}$ & $\begin{array}{l}-0.017 \\
(0.014)\end{array}$ & $\begin{array}{c}0.012 \\
(0.023)\end{array}$ \\
\hline \multicolumn{2}{|l|}{ father's age } & $\begin{array}{c}0.021 \\
(0.017)\end{array}$ & $\begin{array}{l}-0.000 \\
(0.000)\end{array}$ & $\begin{array}{c}0.019 \\
(0.013)\end{array}$ & $\begin{array}{c}0.015 \\
(0.016)\end{array}$ & $\begin{array}{l}-0.002 \\
(0.028)\end{array}$ \\
\hline \multicolumn{2}{|l|}{ father's age squared } & $\begin{array}{l}-0.000 \\
(0.000)\end{array}$ & $\begin{array}{c}0.000 \\
(0.000)\end{array}$ & $\begin{array}{l}-0.000^{*} \\
(0.000)\end{array}$ & $\begin{array}{l}-0.000 \\
(0.000)\end{array}$ & $\begin{array}{l}-0.000 \\
(0.000)\end{array}$ \\
\hline \multirow[t]{2}{*}{ educational level } & $\begin{array}{l}\text { low } \\
\text { medium }\end{array}$ & $\begin{array}{c}\text { ref. } \\
-0.055^{*} \\
(0.030)\end{array}$ & $\begin{array}{c}\text { ref. } \\
-0.056 \\
(0.057)\end{array}$ & $\begin{array}{c}\text { ref. } \\
-0.006 \\
(0.023)\end{array}$ & $\begin{array}{c}\text { ref. } \\
-0.038 \\
(0.025)\end{array}$ & $\begin{array}{c}\text { ref. } \\
-0.061 \\
(0.048)\end{array}$ \\
\hline & high & $\begin{array}{l}0.057^{* *} \\
(0.027)\end{array}$ & $\begin{array}{c}0.016 \\
(0.057)\end{array}$ & $\begin{array}{c}0.071 * * * \\
(0.021)\end{array}$ & $\begin{array}{l}0.062^{* *} \\
(0.028)\end{array}$ & $\begin{array}{l}-0.004 \\
(0.047)\end{array}$ \\
\hline \multirow[t]{3}{*}{ fathers' employment } & $\begin{array}{l}\text { not employed } \\
\text { part-time }\end{array}$ & $\begin{array}{c}\text { ref. } \\
-0.150 \\
(0.104)\end{array}$ & $\begin{array}{c}\text { ref. } \\
0.086 \\
(0.095)\end{array}$ & $\begin{array}{c}\text { ref. } \\
0.029 \\
(0.063)\end{array}$ & $\begin{array}{c}\text { ref. } \\
-0.066 \\
(0.084)\end{array}$ & $\begin{array}{c}\text { ref. } \\
0.092 \\
(0.024)\end{array}$ \\
\hline & full-time & $\begin{array}{l}-0.081 \\
(0.052)\end{array}$ & $\begin{array}{l}-0.012 \\
(0.057)\end{array}$ & $\begin{array}{c}0.004 \\
(0.035)\end{array}$ & $\begin{array}{c}-0.131^{* * *} \\
(0.046)\end{array}$ & $\begin{array}{l}0.114^{*} \\
(0.068)\end{array}$ \\
\hline & $\begin{array}{l}\text { unknown work } \\
\text { hours }\end{array}$ & - & $\begin{array}{c}0.153 \\
(0.118)\end{array}$ & $\begin{array}{l}0.161^{*} \\
(0.071)\end{array}$ & $\begin{array}{c}0.077 \\
(0.155)\end{array}$ & $\begin{array}{c}0.222 \\
(0.143)\end{array}$ \\
\hline \multirow{4}{*}{$\begin{array}{l}\text { partner's } \\
\text { employment }\end{array}$} & not employed & ref. & ref. & ref. & ref. & ref. \\
\hline & part-time & $\begin{array}{c}0.011 \\
(0.028)\end{array}$ & $\begin{array}{c}0.011 \\
(0.034)\end{array}$ & $\begin{array}{l}-0.004 \\
(0.020)\end{array}$ & $\begin{array}{c}0.008 \\
(0.025)\end{array}$ & $\begin{array}{c}0.023 \\
(0.041)\end{array}$ \\
\hline & full-time & $\begin{array}{l}0.0201 \\
(0.031)\end{array}$ & $\begin{array}{c}0.030 \\
(0.043)\end{array}$ & $\begin{array}{l}-0.021 \\
(0.023)\end{array}$ & $\begin{array}{c}0.022 \\
(0.029)\end{array}$ & $\begin{array}{l}-0.052 \\
(0.059)\end{array}$ \\
\hline & $\begin{array}{l}\text { unknown work } \\
\text { hours }\end{array}$ & - & $\begin{array}{c}0.051 \\
(0.039)\end{array}$ & $\begin{array}{c}0.016 \\
(0.032)\end{array}$ & $\begin{array}{c}0.107^{* *} \\
(0.043)\end{array}$ & $\begin{array}{c}0.018 \\
(0.024)\end{array}$ \\
\hline day of the week & $\begin{array}{l}\text { weekday } \\
\text { weekend }\end{array}$ & $\begin{array}{c}\text { ref. } \\
0.036 \\
(0.027)\end{array}$ & $\begin{array}{c}\text { ref. } \\
-0.025 \\
(0.028)\end{array}$ & $\begin{array}{c}\text { ref. } \\
-0.004 \\
(0.018)\end{array}$ & $\begin{array}{c}\text { ref. } \\
0.004 \\
(0.020)\end{array}$ & $\begin{array}{c}\text { ref. } \\
-0.000 \\
(0.011)\end{array}$ \\
\hline \multicolumn{2}{|c|}{ housework participation } & $\begin{array}{c}0.223^{* * *} \\
(0.024)\end{array}$ & $\begin{array}{c}0.195^{* * *} \\
(0.028)\end{array}$ & $\begin{array}{c}0.193^{* * *} \\
(0.022)\end{array}$ & $\begin{array}{c}0.197 * * * \\
(0.021)\end{array}$ & $\begin{array}{c}0.246^{* * *} \\
(0.038)\end{array}$ \\
\hline \multirow[t]{2}{*}{ time of survey } & wave 1 & - & - & $\begin{array}{c}-0.057^{* * *} \\
(0.020)\end{array}$ & $\begin{array}{c}0.028 \\
(0.027)\end{array}$ & $\begin{array}{c}0.017 \\
(0.040)\end{array}$ \\
\hline & wave 2 & - & - & ref. & ref. & ref. \\
\hline Pseudo R2 & & 0.2024 & 0.1825 & 0.1681 & 0.1850 & 0.2269 \\
\hline
\end{tabular}

Significance levels: $\mathrm{p}<0.01:^{* * *}, \mathrm{p}<0.05:^{* *}, \mathrm{p}<0.10:^{*}, \mathrm{p}<0.11:(*)$

Sources: MTUS (2010); own calculations. 
Table A2.2: Participating fathers' minutes of childcare in Germany - sensitivity analysis OLS model, dependent variable: minutes of childcare. Table shows b-coefficients, standard errors in parenthesis.

\begin{tabular}{|c|c|c|c|c|c|c|c|}
\hline & & $\begin{array}{l}\text { only } 1991 \\
(\mathrm{~N}=1214)\end{array}$ & $\begin{array}{l}\text { only } 2001 \\
(\mathrm{~N}=808)\end{array}$ & $\begin{array}{c}2 \text {-day- } \\
\text { average } \\
(\mathrm{N}=2022)\end{array}$ & $\begin{array}{c}\begin{array}{c}\text { only } \\
\text { week-days }\end{array} \\
(\mathrm{N}=1415)\end{array}$ & $\begin{array}{c}\text { only } \\
\text { weekend- } \\
\text { days } \\
(\mathrm{N}=607)\end{array}$ & $\begin{array}{c}\text { 2-step } \\
\text { Heckman } \\
(\mathrm{N}=2022)\end{array}$ \\
\hline \multirow{3}{*}{$\begin{array}{l}\text { age of the } \\
\text { youngest child }\end{array}$} & $0-4$ & ref. & ref. & ref. & ref. & ref. & ref. \\
\hline & $5-12$ & $\begin{array}{c}-2497^{* * *} \\
(4.32)\end{array}$ & $\begin{array}{c}-23.73^{* * *} \\
(5.44)\end{array}$ & $\begin{array}{c}-31.65^{* * *} \\
(2.48)\end{array}$ & $\begin{array}{c}-17.31^{* * *} \\
(3.48)\end{array}$ & $\begin{array}{c}-53.64^{* * *} \\
(7.63)\end{array}$ & $\begin{array}{c}-27.01^{* * *} \\
(5.19)\end{array}$ \\
\hline & $13-17$ & $\begin{array}{c}-37.27^{* * *} \\
(6.53)\end{array}$ & $\begin{array}{c}-32.91^{* * *} \\
(8.10)\end{array}$ & $\begin{array}{c}-44.37 * * * \\
(3.68)\end{array}$ & $\begin{array}{c}-31.22^{* * *} \\
(5.12)\end{array}$ & $\begin{array}{c}-53.97 * * * \\
(12.53)\end{array}$ & $\begin{array}{c}- \\
33.76^{* * *}(11.29\end{array}$ \\
\hline \multicolumn{2}{|l|}{ no. of children } & $\begin{array}{c}0.98 \\
(3.17)\end{array}$ & $\begin{array}{c}-6.60^{* *} \\
(3.02)\end{array}$ & $\begin{array}{l}-2.86^{*} \\
(1.56)\end{array}$ & $\begin{array}{c}-5.83^{* * *} \\
(1.70)\end{array}$ & $\begin{array}{l}10.56^{*} \\
(5.93)\end{array}$ & $\begin{array}{l}-1.23 \\
(2.21)\end{array}$ \\
\hline \multicolumn{2}{|l|}{ father's age } & $\begin{array}{c}0.41 \\
(3.42)\end{array}$ & $\begin{array}{c}1.05 \\
(4.60)\end{array}$ & $\begin{array}{c}2.54 \\
(1.83)\end{array}$ & $\begin{array}{c}2.72 \\
(2.05)\end{array}$ & $\begin{array}{l}-1.51 \\
(5.66)\end{array}$ & $\begin{array}{c}1.16 \\
(2.22)\end{array}$ \\
\hline $\begin{array}{l}\text { father's age } \\
\text { squared }\end{array}$ & & $\begin{array}{l}-0.01 \\
(0.05)\end{array}$ & $\begin{array}{l}-0.02 \\
(0.05)\end{array}$ & $\begin{array}{l}-0.04 \\
(0.02)\end{array}$ & $\begin{array}{l}-0.04 \\
(0.03)\end{array}$ & $\begin{array}{c}0.02 \\
(0.07)\end{array}$ & $\begin{array}{l}-0.02 \\
(0.03)\end{array}$ \\
\hline \multirow[t]{2}{*}{ educational level } & $\begin{array}{l}\text { low } \\
\text { medium }\end{array}$ & $\begin{array}{c}\text { ref. } \\
-1.62 \\
(4.85)\end{array}$ & $\begin{array}{c}\text { ref. } \\
-4.70 \\
(10.20)\end{array}$ & $\begin{array}{c}\text { ref. } \\
-2.31 \\
(3.12)\end{array}$ & $\begin{array}{c}\text { ref. } \\
-3.71 \\
(4.12)\end{array}$ & $\begin{array}{c}\text { ref. } \\
-14.88^{*} \\
(8.91)\end{array}$ & $\begin{array}{l}\text { selection } \\
\text { variable }\end{array}$ \\
\hline & high & $\begin{array}{l}0.086 \\
(4.28)\end{array}$ & $\begin{array}{c}2.51 \\
(10.04)\end{array}$ & $\begin{array}{c}6.49^{* *} \\
(3.02)\end{array}$ & $\begin{array}{c}3.95 \\
(3.64)\end{array}$ & $\begin{array}{c}0.37 \\
(8.82)\end{array}$ & \\
\hline \multirow{4}{*}{$\begin{array}{l}\text { fathers' } \\
\text { employment }\end{array}$} & not employed & ref. & ref. & ref. & ref. & ref. & ref. \\
\hline & part-time & $\begin{array}{c}-3.77 \\
(19.13)\end{array}$ & $\begin{array}{l}-15.48 \\
(16.72)\end{array}$ & $\begin{array}{l}-1.47 \\
(9.61)\end{array}$ & $\begin{array}{c}-26.21^{* *} \\
(11.48)\end{array}$ & $\begin{array}{c}33.78 \\
(32.69)\end{array}$ & $\begin{array}{c}-7.95 \\
(12.08)\end{array}$ \\
\hline & full-time & $\begin{array}{l}-9.68 \\
(8.54)\end{array}$ & $\begin{array}{c}-24.00^{* *} \\
(11.85)\end{array}$ & $\begin{array}{c}-17.42^{* * *} \\
(6.07)\end{array}$ & $\begin{array}{c}-20.98^{* * *} \\
(7.75)\end{array}$ & $\begin{array}{c}-0.41 \\
(15.05)\end{array}$ & $\begin{array}{c}-15.23^{* *} \\
(7.03)\end{array}$ \\
\hline & $\begin{array}{l}\text { unknown work } \\
\text { hours }\end{array}$ & - & $\begin{array}{l}-35.41 \\
(23.71)\end{array}$ & $\begin{array}{l}-21.02 \\
(13.82)\end{array}$ & $\begin{array}{l}-25.20 \\
(28.24)\end{array}$ & $\begin{array}{l}-33.45^{*} \\
(19.61)\end{array}$ & $\begin{array}{l}-28.25 \\
(22.14)\end{array}$ \\
\hline \multirow{4}{*}{$\begin{array}{l}\text { partner's } \\
\text { employment }\end{array}$} & not employed & ref. & ref. & ref. & ref. & ref. & ref. \\
\hline & part-time & $\begin{array}{l}-0.76 \\
(4.67)\end{array}$ & $\begin{array}{l}-5.14 \\
(5.26)\end{array}$ & $\begin{array}{l}-3.12 \\
(5.57)\end{array}$ & $\begin{array}{l}-6.41 \\
(3.39)\end{array}$ & $\begin{array}{c}4.43 \\
(8.02)\end{array}$ & $\begin{array}{l}-2.67 \\
(3.51)\end{array}$ \\
\hline & full-time & $\begin{array}{l}-1.56 \\
(5.16)\end{array}$ & $\begin{array}{l}-1.08 \\
(7.28)\end{array}$ & $\begin{array}{l}-4.85 \\
(3.30)\end{array}$ & $\begin{array}{l}-1.17 \\
(4.48)\end{array}$ & $\begin{array}{l}-8.57 \\
(8.46)\end{array}$ & $\begin{array}{l}-2.36 \\
(4.11)\end{array}$ \\
\hline & $\begin{array}{l}\text { unknown work } \\
\text { hours }\end{array}$ & - & $\begin{array}{l}-2.88 \\
(5.92)\end{array}$ & $\begin{array}{l}-4.65 \\
(3.92)\end{array}$ & $\begin{array}{l}-9.25 \\
(5.74)\end{array}$ & $\begin{array}{c}11.17 \\
(11.37)\end{array}$ & $\begin{array}{l}-2.26 \\
(5.30)\end{array}$ \\
\hline day of the week & $\begin{array}{l}\text { weekday } \\
\text { weekend }\end{array}$ & $\begin{array}{c}\text { ref. } \\
27.92^{* * *} \\
(5.17)\end{array}$ & $\begin{array}{c}\text { ref. } \\
18.27^{* * *} \\
(5.14)\end{array}$ & $\begin{array}{c}\text { ref. } \\
8.28^{* * *} \\
(2.63)\end{array}$ & $\begin{array}{l}- \\
-\end{array}$ & - & $\begin{array}{c}\text { ref. } \\
23.79^{* * *} \\
(3.70)\end{array}$ \\
\hline \multicolumn{2}{|c|}{ minutes of housework } & $\begin{array}{l}0.19 * * * \\
(0.065)\end{array}$ & $\begin{array}{c}0.13^{* * *} \\
(0.06)\end{array}$ & $\begin{array}{c}0.14^{* * * *} \\
(0.03)\end{array}$ & $\begin{array}{c}0.186^{* * *} \\
(0.04)\end{array}$ & $\begin{array}{l}0.11^{* *} \\
(0.05)\end{array}$ & $\begin{array}{c}0.16^{* * *} \\
(0.04)\end{array}$ \\
\hline \multirow[t]{2}{*}{ time of survey } & wave 1 & - & - & $\begin{array}{c}-9.65 * * * \\
(2.85)\end{array}$ & $\begin{array}{c}-11.17^{* * *} \\
(3.87)\end{array}$ & $\begin{array}{c}-16.47^{* *} \\
(7.90)\end{array}$ & $\begin{array}{c}-12.64^{* * *} \\
(3.40)\end{array}$ \\
\hline & wave 2 & - & - & - & ref. & ref. & ref. \\
\hline constant & & $\begin{array}{c}61.54 \\
(58.74)\end{array}$ & $\begin{array}{c}96.17 \\
(97.10)\end{array}$ & $\begin{array}{c}51.79 \\
(36.32)\end{array}$ & $\begin{array}{c}50.78^{* * *} \\
(40.44)\end{array}$ & $\begin{array}{c}127.63 \\
(107.14)\end{array}$ & $\begin{array}{l}74.20^{*} \\
(42.15)\end{array}$ \\
\hline lambda & & & & & & & $\begin{array}{c}-3.41 \\
(10.07) \\
\end{array}$ \\
\hline R2 & & 0.1402 & 0.1504 & 0.1782 & 0.1051 & 0.1399 & 0.1241 \\
\hline
\end{tabular}

Significance levels: $\mathrm{p}<0.01:^{* * *}, \mathrm{p}<0.05:^{* *}, \mathrm{p}<0.10:^{*}, \mathrm{p}<0.11:\left({ }^{*}\right)$

Sources: MTUS (2010); own calculations. 


\section{HWWI Research Papers}

since 2011

115 Fathers' Childcare and Parental Leave Policies - Evidence from Western European Countries and Canada

Nora Reich, Christina Boll, Julian Leppin, Hamburg, February 2012

114 What Drives FDI from Non-traditional Sources? A Comparative Analysis of the Determinants of Bilateral FDI Flows

Maximiliano Sosa Andrés, Peter Nunnenkamp, Matthias Busse, Hamburg, January 2012

113 On the predictive content of nonlinear transformations of lagged autoregression residuals and time series observations Anja Rossen, Hamburg, October 2011

112 Regional labor demand and national labor market institutions in the EU15 Helmut Herwartz, Annekatrin Niebuhr, Hamburg, October 2011

111 Unemployment Duration in Germany - A comprehensive study with dynamic hazard models and P-Splines

Torben Kuhlenkasper, Max Friedrich Steinhardt, Hamburg, September 2011

110 Age, Life-satisfaction, and Relative Income

Felix FitzRoy, Michael Nolan, Max Friedrich Steinhardt, Hamburg, July 2011

109 The conjoint quest for a liberal positive program: "Old Chicago", Freiburg and Hayek

Ekkehard Köhler, Stefan Kolev, Hamburg, July 2011

108 Agglomeration, Congestion, and Regional Unemployment Disparities Ulrich Zierahn, Hamburg, July 2011

107 Efficient Redistribution: Comparing Basic Income with Unemployment Benefit Felix FitzRoy, Jim Jin, Hamburg, March 2011

106 The Resource Curse Revisited: Governance and Natural Resources Matthias Busse, Steffen Gröning, Hamburg, March 2011

105 Regional Unemployment and New Economic Geography Ulrich Zierahn, Hamburg, March 2011

104 The Taxation-Growth-Nexus Revisited K. P. Arin, M. Berlemann, F. Koray, T. Kuhlenkasper, Hamburg, January 2011 
The Hamburg Institute of International Economics (HWWI) is an independent economic research institute, based on a non-profit public-private partnership, which was founded in 2005. The University of Hamburg and the Hamburg Chamber of Commerce are shareholders in the Institute .

The HWWI's main goals are to:

- Promote economic sciences in research and teaching;

- Conduct high-quality economic research;

- Transfer and disseminate economic knowledge to policy makers, stakeholders and the general public.

The HWWI carries out interdisciplinary research activities in the context of the following research areas:

- Economic Trends and Global Markets,

- Regional Economics and Urban Development,

- Sectoral Change: Maritime Industries and Aerospace,

- Institutions and Institutional Change,

- Energy and Raw Material Markets,

- Environment and Climate,

- Demography, Migration and Integration,

- Labour and Family Economics,

- Health and Sports Economics,

- Family Owned Business, and

- Real Estate and Asset Markets. 
Hamburg Institute of International Economics (HWWI)

Heimhuder Str. 71 | 20148 Hamburg | Germany

Phone: +49 (0)40 340576 - 0 | Fax: +49 (0)40 340576 - 776

info@hwwi.org | www.hwwi.org 